\title{
Isoflavones and the prevention of breast and prostate cancer: new perspectives opened by nutrigenomics
}

\author{
Claudia Steiner ${ }^{1}$, Stéphanie Arnould ${ }^{2}$, Augustin Scalbert ${ }^{1}$ and Claudine Manach ${ }^{1 *}$ \\ ${ }^{1}$ INRA, UMR 1019, Unité Nutrition Humaine, Centre Clermont-Theix, F-63122 St Genès Champanelle, France \\ ${ }^{2}$ Laboratoire d'Oncologie Moléculaire, UMR 484 INSERM-UdA, Centre Jean Perrin, F-63011 Clermont-Ferrand, France
}

Epidemiological evidence together with preclinical data from animal and in vitro studies strongly support a correlation between soy isoflavone consumption and protection towards breast and prostate cancers. The biological processes modulated by isoflavones, and especially by genistein, have been extensively studied, yet without leading to a clear understanding of the cellular and molecular mechanisms of action involved. This review discusses the existing gaps in our knowledge and evaluates the potential of the new nutrigenomic approaches to improve the study of the molecular effects of isoflavones. Several issues need to be taken into account for the proper interpretation of the results already published for isoflavones. Too often knowledge on isoflavone bioavailability is not taken into account; supra-physiological doses are frequently used. Characterization of the individual variability as defined by the gut microflora composition and gene polymorphisms may also help to explain the discrepancies observed so far in the clinical studies. Finally, the complex inter-relations existing between tissues and cell types as well as cross-talks between metabolic and signalling pathways have been insufficiently considered. By appraising critically the abundant literature with these considerations in mind, the mechanisms of action that are the more likely to play a role in the preventive effects of isoflavones towards breast and prostate cancers are reviewed. Furthermore, the new perspectives opened by the use of genetic, transcriptomic, proteomic and metabolomic approaches are highlighted.

Isoflavones: prostate cancer: breast cancer: chemoprevention: nutrigenomics

Isoflavones are a class of bioactive phytochemicals that have been widely studied for their potential role in the prevention of various chronic diseases, such as cardiovascular diseases, neurodegenerative diseases, osteoporosis, cancers... Soy and its processed products (tofu, tempeh, miso, natto, soymilk, soy-based yoghurts and desserts) are the only sources providing high quantities of isoflavones in the human diet. Isoflavone intake has been estimated to $25-50 \mathrm{mg} /$ day in Asian countries, with a maximum around $100 \mathrm{mg} / \mathrm{d}$ for elderly Japanese men ${ }^{(1)}$. Americans and Europeans, who have low soy content in their habitual diet, only consume few milligrams of isoflavones per day. However, advertising on the beneficial effects of isoflavones, especially for relieving postmenopausal symptoms, has led to self-supplementation through isoflavone-rich foods or dietary supplements. Isoflavones in soybeans mainly include daidzein, genistein and glycitein, which are present in glycosylated or aglycone forms (Fig. 1). The structural similarity of aglycones with $17 \beta$-estradiol gives them the capacity to bind estrogen receptors (ERs) and to induce hormone-like effects. Isoflavones and their protective role against various pathologies involving hormonal dysregulation have been extensively studied because of this particular property.

The current evidence provided by preclinical studies on the role of isoflavones in reducing prostate and breast cancer risk has been recently reviewed ${ }^{(2-4)}$. A summary of the main data available will be made here, to highlight the present limitations in our understanding of their mechanisms of action, and to evaluate the potential of nutrigenomic approaches to further clarify these mechanisms.

\section{Human studies}

The lower risk of prostate and breast cancer in areas of high soy and isoflavone intake, especially in $\mathrm{Asia}^{(5)}$, as well as the increased risk observed for Asian people who migrated to Western countries or adopted a westernised lifestyle ${ }^{(6-8)}$

Abbreviations: AF, activation functions; AP-1, activator protein 1; AR, androgen receptor; CDK, cyclin-dependent kinase; COMT, catechol- $O$-methyltransferase; CYP, cytochrome P450 monooxygenase; Da, daidzein; DHEA, dihydroepiandrosterone; DHT, dihydrotestosterone; EGF, epidermal growth factor; EGFR, epidermal growth factor receptor; Eq, equol; ER, estrogen receptor; ERE, estrogen responsive elements; ERK, extracellular signal-regulated kinase 1; FSH, follicel-stimulating hormone; Ge, genistein; GPx, glutathione peroxidase; GSR, glutathione reductase; GST, glutathione S-transferase; GTP-CH1, GTP cyclohydrolase 1; IGF-1, insulin-like growth factor 1; IGF-1R, insulin-like growth factor 1 receptor; IGFBP, insulin-like growth factor binding protein; JNK, c-jun N-terminal kinase; LDL, low density lipoprotein; LH, luteinising hormone; MAPK, mitogen-activated protein kinase; MMP, matrix metalloproteinase; MS, mass spectrometry; MT-1X, metallothionein 1X; mGST, microsomal glutathione S-transferase; NF-кB, nuclear factor-kappa B; NMR, nuclear magnetic resonance; PI3K, phosphatidylinositol-3 kinase; PIN, prostatic intra-epithelial neoplasia; PPAR, peroxisome proliferator-activated receptor; PR, progesterone receptor; PSA, prostate specific antigen; QR, quinone reductase; SD rats, Sprague-Dawley rats; SHBG, sex hormone binding globulin; SNPs, single nucleotide polymorphisms; SOD, superoxide dismutase; TEBs, terminal end buds; TGF- $\beta$, transforming growth factor $\beta$; TIMP, tissue inhibitor of metalloproteinase; TRAMP, transgenic adenocarcinoma of the mouse prostate; UDPGT, UDP-glucuronosyl-transferase; VEGFR, vascular endothelial growth factor receptor.

* Corresponding author: C. Manach, fax +334736246 38, email manach@clermont.inra.fr 
$\mathrm{HO}$<smiles>O=c1c(-c2ccc(O)cc2)coc2cccc(O)c12</smiles>
Genistein<smiles>O=c1c(-c2ccc(O)cc2)coc2cc(O)ccc12</smiles>

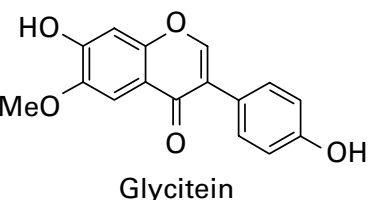

$\mathrm{HO}$

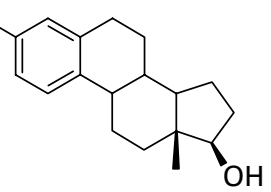

$17 \beta$-Estradiol
Fig. 1. Structures of the soy isoflavones genistein, daidzein and glycitein in comparison to $17 \beta$-estradiol.

are well known. A recent meta-analysis compiling 2 cohort studies and 6 case-control studies in Western and Asian populations estimated that high soy food intake can be related to a $30 \%$ reduction in prostate cancer risk (odds ratio 0.70 , $95 \%$ CI $0.59-0 \cdot 83)^{(9)}$. For breast cancer, a smaller risk reduction (odds ratio $0 \cdot 86,95 \%$ CI $0 \cdot 75-0.99$ ), stronger for premenopausal women, was found in a meta-analysis compiling 6 cohort and 12 case-control studies ${ }^{(10)}$. Asian women whose soy intake was high during puberty experienced lower risk for breast cancer than women who did not consume soy products or did only as adults ${ }^{(11,12)}$.

Among hundreds of dietary components that have been proposed as potential cancer preventive agents, only a few have been used in clinical trials. The impact of isoflavone supplementation has been studied on some prostate cancer-related endpoints such as serum levels of Prostate-Specific Antigen (PSA), PSA velocity, plasma levels of testosterone, dihydrotestosterone (DHT), insulin-like growth factor 1 (IGF-1) and IGF binding protein 3 (IGFBP-3). Among the 11 trials recently reviewed by Messina et al. ${ }^{(13)}$, only 4 reported a significant effect on PSA levels. However, reduction in prostate cancer risk may occur without any reduction in PSA levels. No beneficial effects were observed on levels of steroids, or on IGF-1/IGFBP-3 ratio. One study which compared the incidence of apoptosis in prostate tumours of patients supplemented or not with red clover isoflavones $(160 \mathrm{mg} / \mathrm{d}$ for 7-54 days), reported significantly higher apoptosis in supplemented patients than in control subjects $(1.48 \% \quad v$. $0.25 \%, P=0.0007)$, specifically in regions of low to moderate-grade cancer (Gleason grade $1-3)^{(14)}$. It is worth noting that no adverse effects were observed in any trial. The whole available data have been considered sufficiently encouraging to justify the funding of additional Phase II trials by the $\mathrm{NIH}^{(13)}$.

Messina et al. ${ }^{(15)}$ recently discussed the published and ongoing clinical breast cancer studies. Three double-blind randomized controlled trials reported no effect of a 1 to 2-year isoflavone supplementation on mammographic density used as a marker of breast cancer risk $^{(16-18)}$. A 2-week administration of a soy supplement $(45 \mathrm{mg} / \mathrm{d}$ isoflavones) increased epithelial cell proliferation and progesterone receptor (PR) expression in normal breast tissue, suggesting an estrogen agonist effect ${ }^{(19)}$. However, the potential link with proliferation of breast cancer cells is difficult to assess. Conflicting results have been obtained regarding the impact of soy isoflavones on hormone-related breast cancer risk factors such as plasma steroid hormone levels, Sex Hormone Binding Globulin (SHBG) plasma levels, urinary 2:16 $\alpha$-hydroxyestrone ratio, and menstrual cycle length ${ }^{(20)}$.

The inconsistencies in the results and the failure to observe clear clinical effects may be explained, at least in part, by disparities in experimental designs, in the form of isoflavone administration, the dose, or the duration of the study. Furthermore, diverse subpopulations may respond differently to isoflavone consumption due to age, sex, ethnic background, gene polymorphisms, history of cancer, known risk factors, nutritional status, hormonal status or colonic microbiota composition. In this regard, the most critical parameters affecting the biological responses to isoflavone intake remain to be identified. The populations or subpopulations which may benefit, or possibly may experience some adverse effects while consuming isoflavones, also need to be identified.

The factors likely to affect isoflavone bioavailability may first modulate physiological responses to isoflavone intake. A compilation of 15 bioavailability studies in humans showed that plasma metabolite concentrations usually reach about $2 \mu \mathrm{mol} / \mathrm{l}$ after consumption of $50 \mathrm{mg}$ isoflavones (aglycone equivalent) ${ }^{(21)}$. Inter-individual variability in isoflavone absorption and metabolism has never been assessed in large and ethnically non-homogeneous populations, however some bioavailability studies suggest that it may be high. Maximum plasma concentrations ranged between 4 and $27 \mu \mathrm{mol} / \mathrm{l}$ genistein among 20 American men with prostate cancer challenged with a high pharmacological dose of genistein ${ }^{(22)}$. Furthermore, a recent clinical study showed that genistein and daidzein bioavailability, evaluated by plasma pharmacokinetics, was significantly lower in Caucasian than in Asian men after single or 10-day isoflavone supplementation ${ }^{(23)}$. It would therefore be extremely useful to accurately measure the real individual exposure to isoflavones rather than only the isoflavone intake in clinical studies.

The intestinal microflora also plays a crucial role in the metabolism of isoflavones. Various bacterial metabolites are known to be produced, among which some may exert biological activities ${ }^{(24-26)}$. Equol is the most studied metabolite since it has been shown to be more estrogenic than its precursor daidzein in many in vitro studies and in animal models ${ }^{(27)}$. There is great inter-individual variability in the capacity to produce equol, and only $30-50 \%$ of the Western population exhibits the 'equol-producer' phenotype ${ }^{(28)}$. Song et al. recently reported that the equol-producer phenotype was more frequent in Korean American than in Caucasian American women $(51 \%$ v. $36 \%)$ living in the same area of the US ${ }^{(29)}$. Several studies suggested that equol-producers may gain more benefits from soy consumption than nonequol-producers. In a case-control study in Japanese and Korean men, the proportion of equol-producers was 1.5- to 2 -fold higher in the control group than in the group of men with prostate cancer ${ }^{(30)}$. More favourable hormonal profiles (lower plasma concentrations of estrone, estrone-sulfate, testosterone, androstenedione, dehydroepiandrosterone (DHEA), DHEA-sulfate, and midluteal progesterone) and higher concentrations of SHBG were also found in equol-producing premenopausal women compared to non-equol-producers, which was consistent with a lower risk for breast cancer $^{(31)}$. Frankenfeld et al. did not find such hormonal 
differences in postmenopausal women, but equol-producing women had higher 2:16 $\alpha$-hydroxyestrone ratio, which has also been related to a lower breast cancer risk $^{(32)}$. Similar results were obtained in breast cancer survivors ${ }^{(33)}$. Mammographic density was $39 \%$ lower in equol-producing postmenopausal women compared with non-producers, which is again consistent with a lower breast cancer risk in equolproducers ${ }^{(34)}$. Niculescu et al. studied the effects of a highdose isoflavone supplementation $(900 \mathrm{mg} / \mathrm{d}$ for 84 days) on gene expression changes in lymphocytes of 30 postmenopausal women. Using microarray analysis they showed that isoflavone treatment in equol-producer subjects differentially affects gene expression as compared with non-producers, with a stronger effect on some estrogen-responsive genes in equol-producers ${ }^{(35)}$. It is not yet clear whether equol itself is the active metabolite responsible for these beneficial effects, or whether it is only a biomarker for a particular microbial community composition able to elicit favourable metabolisms in addition to equol production. Some fingerprinting methods, such as terminal restriction fragment length polymorphism (TRFLP) analysis, are now available to compare the overall patterns of gut microbial composition between individuals ${ }^{(36)}$. These high-throughput methods should enlighten the role of specific bacteria and help to adequately stratify individuals in future human intervention and observational population-based studies.

Metabolomics is another high-throughput method that may be useful to deal with inter-individual variability. Nuclear magnetic resonance (NMR) and mass spectrometry (MS) techniques allow the simultaneous detection of hundreds or thousands of compounds present in human plasma, urine or tissues ${ }^{(37)}$. Multivariate statistical analyses of the datasets obtained for groups of individuals that differ for one controlled criterion, such as isoflavone intake, microflora composition or type of cancer, provide a list of variables discriminating the groups. The identification of these discriminating variables may lead to the discovery of novel biomarkers for the particular criterion studied. Metabolic profiling using these biomarkers could then be used in clinical or cohort studies to better assess individual exposure to isoflavones, as well as to stratify individuals on the basis of their metabolic capacities or other phenotypes.

Another new possibility, offered by nutrigenetics, is the access to valuable information on individual genotypes through sequencing of targeted single nucleotide polymorphisms (SNPs) ${ }^{(38)}$. As some polymorphisms in genes coding for membrane transporters, protein carriers or metabolic enzymes such as glucuronosyl-transferases could affect the nature and concentrations of isoflavone metabolites present in target tissues, it may be useful to search for correlations between individual genotypes, isoflavone bioavailability and isoflavone effects. However, the relevant SNPs that would be related to the responsiveness to isoflavone consumption are not identified to date. Beyond the gene polymorphisms that may affect bioavailability, two recent studies demonstrated the major interest of considering the inter-individual variability in the genetic background of a population to evaluate the isoflavone biological effects. Hedelin et al. studied the interactions between dietary phytoestrogen intake, ER $\beta$ polymorphisms, and the risk of prostate cancer in a case-control study performed in 2096 Swedish men ${ }^{(39)}$.
For one particular SNP of the ER $\beta$ gene, a higher phytoestrogen and isoflavone consumption was associated to a significantly reduced prostate cancer risk (respectively $57 \%$ and $27 \%$ ) in subjects who were homozygous or heterozygous for the variant allele, whereas no association could be found in subjects who were homozygous for the wildtype allele (58\% of the population). In another cohort of 1988 menopausal women from UK, isoflavone exposure was positively associated with SHBG levels only in the fraction of the population that carried the Asn variant of the SHBG D356N polymorphism, which is associated with a reduced SHBG clearance ${ }^{(40)}$. As higher SHBG levels have been associated with a lower breast cancer risk, isoflavone consumption may be particularly beneficial to these women. It is worth noticing that the authors would have concluded that isoflavone exposure was not associated to SHBG levels if they had considered the population as a whole, without stratification according to the genotype. Gene-isoflavone interactions may partly explain some of the discrepancies observed in the first clinical studies conducted so far, especially if the allele frequencies differed between the populations considered. Nevertheless, high statistical powered studies will be required in order to take the relevant gene polymorphisms into account in the investigation of isoflavone effects.

Another element that may explain the inconsistencies observed in clinical studies is the relevance of the endpoint biomarkers used. Biomarkers for staging and monitoring the evolution of prostate and breast cancer development are critically needed to evaluate the impact of any therapeutic intervention. Considering that cancers are multi-factorial and variable diseases, it appears today unrealistic to rely on a single biomarker (such as PSA for prostate cancer) to assess diagnosis, prognosis, and prediction of response to therapy. Complex combinations of markers coming from transcriptomic, proteomic as well as metabolomic approaches are certainly more appropriate and promising perspectives can already be seen. Rhodes et al. have analysed gene expression profiles in 40 published cancer microarray data sets, comprising 38 million gene expression measurements from $>3700$ cancer samples ${ }^{(41)}$. This study generated a set of 69 genes that were commonly dysregulated in 12 types of cancers including prostate and breast cancers. Proteomic data have also been used on a blinded cohort to identify patients with prostate cancer with a high specificity ${ }^{(41-43)}$. There is now a great hope that these high-throughput methods will lead to the discovery of early biomarkers for preclinical metabolic dysregulations associated with the first stages of carcinogenesis. Many novel important genes involved in prostate carcinogenesis, such as Hepsin or Alpha-methylacyl-CoA racemase (AMACR), have been identified by using microarray analysis $^{(44)}$. NMR-based metabolomic analyses to target biomarkers for prostate cancer are under development ${ }^{45}$. Novel early biomarkers will improve our understanding of the initial stages of the diseases and will be essential to study the preventive effects of dietary intervention such as isoflavone supplementation.

Therefore, nutrigenomic approaches should allow to better assess individual metabolism and to better evaluate the effects of isoflavones at the individual level and at early stages of the diseases. 


\section{Animal studies}

As demonstrated above, human studies are still hampered with major weaknesses, and more controllable animal and cellular models are very useful to investigate isoflavone effects. Different animal models of prostate cancer such as LobundWistar rats (spontaneous tumours), rats treated with various type of carcinogens [ $N$-methylnitrosourea (NMU), 7,12dimethylbenz $(a)$ anthracene (DMBA), 2-amino-1-methyl-6phenylimidazopyridine (PhIP)] or implants of testosterone propionate, transgenic mice (TRAMP), xenograft models (e.g. immunodeficient mice implanted with human tumour cell lines) have been used to explore the effects of isoflavones on prostate cancers. In more than 40 such studies, isoflavones were shown to reduce both the incidence and the size of prostate tumours ${ }^{(2,3,46)}$. Isoflavones may act at different stages of carcinogenesis, by inhibiting the appearance of prostatic intra-epithelial neoplasia (PIN) or their progression into carcinomas, but the determination of their timing of action requires further experiments.

Much more conflicting results have been obtained in animal models of breast cancer, as isoflavones have been shown to inhibit as well as to promote the growth of mammary tumours, depending on the studies. Many parameters may explain such discrepancies including the various natures of the animal models used, the test compounds, the dose and the mode of administration, or the timing of isoflavone exposure. Overall, isoflavones were mainly shown to prevent or to delay chemically-induced mammary carcinogenesis in prepubertal or premenopausal adult female rats. The protective effects of isoflavones at the prepubertal period have been linked to a promotion of early mammary gland differentiation, leading to a decreased number of immature terminal end buds (TEBs), sites for malignant transformation, and an increased number of more differentiated lobules ${ }^{(47-51)}$. Complex crosstalks between steroids, growth factors and other pathways are involved in the differentiation process. Hilakivi-Clarke et al. reported that the pro-differentiating effect of isoflavones was associated with a repression of $\mathrm{ER} \alpha$ and PR expression but an increase of ER $\beta$ expression in mammary glands ${ }^{(52)}$. Lamartiniere et al. suggested that isoflavone exposure in the prepubertal period mainly promotes mammary epithelium differentiation through the transient activation of epidermal growth factor (EGF) signalling pathway ${ }^{(50)}$.

The most frequent types of breast cancer are the estrogendependent breast tumours in postmenopausal women. Widely used animal models for these types of tumours are immunodeficient mice implanted with estrogen-dependent human breast cancer MCF-7 cells, combined with ovariectomy and in some cases with estradiol implants releasing high doses of estradiol that stimulate the growth of MCF-7 implanted cells. The group of Helferich published several consistent studies showing that genistein at nutritionally relevant doses $(0 \cdot 025-0 \cdot 1 \%$ in the diet) stimulates tumour growth or negates the inhibitory effect of tamoxifen in such xenograft models ${ }^{(53-56)}$. In such models the circulating levels of endogenous estrogens are either much lower (ovariectomy) or much higher (estradiol implants) than the physiological levels observed in postmenopausal women. Hence the relevance of the xenograft models to evaluate the effects of weak estrogenic compounds, the activity of which may depend on the levels of endogenous estrogens, has been criticised. Recently, Ju et al. developed a mouse model with slow-growing estrogen-dependent tumours in ovariectomised athymic mice, using silastic implants to deliver estradiol at levels similar to those observed in postmenopausal women ${ }^{(57)}$. Again, genistein administered in the diet at $500 \mathrm{ppm}$ was shown to act in an additive manner with the low levels of circulating estradiol and stimulated the growth of the tumorigenic MCF-7 cells in this model.

Several authors reported that in utero exposure to high-dose isoflavones (s.c. injections) increased the susceptibility of rats to chemically-induced mammary cancers later in life, in the same way as in utero exposure to high levels of endogenous estrogens ${ }^{(49,58)}$. This effect has been related to an increased number of TEBs, and a reduction in epithelial differentiation in the mammary gland. However, other authors reported that a more nutritional exposure to soy protein isolate (but not to genistein alone) in utero through maternal diet protected young adult rats from NMU-induced mammary tumourigenesis ${ }^{(59)}$. Early exposure to isoflavones or at least to genistein before puberty may cause transient and persistent effects on mammary gland development, as well as on hormone receptor levels ${ }^{(60)}$. These imprinting-like effects may thus differ depending on dose and timing of exposure and lead to adverse or beneficial effects in later life.

Dolinoy et al. provided the first evidence that early in utero exposure to genistein can produce permanent epigenetic changes ${ }^{(61)}$. They showed that maternal dietary genistein supplementation $(250 \mathrm{ppm})$ of mice during gestation shifted the coat colour of heterozygous viable yellow agouti $\left(A^{v y} / a\right)$ offspring towards pseudoagouti and decreased the incidence of obesity during adulthood. These marked phenotypic changes were mediated by an increased methylation of six $\mathrm{CpG}$ sites located in a retrotransposon upstream of the Agouti gene which determines coat colour. An exciting hypothesis of research has been put forward with this study. DNA methylation is known to control cellular differentiation in the mammary epithelium. Thus, epigenetic events associated with in utero or prepubertal exposure to genistein may also contribute to the effects observed on animal mammary gland differentiation ${ }^{(62)}$. Such imprinting phenomena are extremely difficult to study in humans. Extrapolation of data from animal models must take into account some differences in isoflavone bioavailability in rodents and in humans. For example, all laboratory animals have been shown to be constitutive equol-producers, and equol is the major circulating metabolite in animals while it is only present in a low proportion in humans ${ }^{(27)}$.

Animal studies also showed that isoflavones exert various effects depending on their structures and application forms. The large majority of studies have been conducted with genistein. When used alone, daidzein was shown to be equivalent to genistein at the same dose $(250 \mathrm{ppm}$ in the diet) in delaying mammary tumour development in MMTV-neu mice ${ }^{(63)}$. In contrast, prepubertal exposure of Sprague-Dawley female rats to $250 \mathrm{ppm}$ daidzein in the diet neither enhanced mammary gland differentiation nor suppressed DMBA-induced mammary tumour development as previously demonstrated for genistein ${ }^{(64)}$. Furthermore, dietary daidzein only had a slight stimulatory effect on MCF-7 tumour growth in athymic mice, whereas $( \pm)$-equol did not stimulate tumour growth ${ }^{(65)}$. Thus, the effects observed with genistein should not be extrapolated 
to other isoflavones, and the various isoflavones may affect different metabolic or signalling pathways. Moreover, consumption of genistein in pure or highly enriched forms (as in soy protein isolates) has a greater stimulatory effect on MCF7 cells implanted in immunodeficient mice than the same content of dietary genistein in less purified soy flour ${ }^{(66)}$. Other authors reported a higher beneficial effect of soymilk or soy protein isolate toward chemically-induced cancer as compared to pure genistein ${ }^{(59,67)}$. Soybeans contain a wide variety of other phytochemicals such as saponins, protease inhibitors like the Bowman-Birk inhibitor, phenolic acids, phytic acid, and lignans that may exert additional or synergistic effects with isoflavones. Taking supplements may thus have different effects than increasing soy food consumption.

\section{Cell models}

Isoflavones have been shown to inhibit proliferation and/or induce apoptosis in various androgen-dependent or androgenindependent prostate cancer cell lines. The concentrations used were generally high, allowing cytotoxic effects, but antiproliferative effects have also been observed at lower concentrations $(5 \mu \mathrm{M})$ of genistein ${ }^{(2,3)}$. Again, the impact of genistein is more complex in breast cancer cell lines than in prostate cell lines, since genistein stimulates cell growth of estrogen-dependent cells when used at concentrations lower than $10 \mu \mathrm{M}$ but inhibits their growth at higher concentrations ${ }^{(3,53,68,69)}$. High concentrations of genistein also inhibit the growth of ER-negative cell lines such as MDA-MB-231, indicating that this isoflavone can exert cellular effects independently from ER.

One major limit of such in vitro studies is that they use isoflavone concentrations far exceeding the concentrations commonly achieved in human plasma or tissues after soy consumption. The available data indicate that concentrations as high as $1-2.5 \mathrm{nmol} / \mathrm{g}$ of each isoflavone may be achieved in human prostate or prostatic fluid after short-term supplementation with high nutritional doses of isoflavones and that in Asian men basal levels of total isoflavones are about $0.4 \mathrm{nmol} / \mathrm{g}$ in prostate ${ }^{(70-74)}$. Isoflavone concentrations in breast tissue are still unknown. Maubach et al. suggested in an isoflavone supplementation study in 9 women, that they may be markedly lower than serum concentrations ${ }^{(75)}$.

The question of the dose is critical, since increasing the dose of exposure does not necessarily produce more intense effects but may also lead to completely different effects. Dang et al. ${ }^{\text {(76) }}$ clearly showed that genistein elicits different biological effects in osteoprogenitor KS483 cells depending on the concentration of exposure. At low concentrations $(<1 \mu \mathrm{M})$, genistein acts as an estrogen, stimulating osteogenesis and inhibiting adipogenesis, whereas at high concentrations $(>1 \mu \mathrm{M})$, it acts as a ligand for PPAR $\gamma$, leading to the upregulation of adipogenesis and downregulation of osteogenesis.

Daidzein and genistein glycosides and aglycones, when ingested with soy foods, are extensively metabolised in the human intestine and liver and systematically recovered in plasma as 7-O- and $4^{\prime}-O$-glucuronides, along with low amounts of aglycones and sulfate esters ${ }^{(77-79)}$. Mono-glucuronides of genistein and daidzein were recently shown to also be the main metabolites present in the human prostate ${ }^{(74)}$. However, the effects of these conjugated forms of isoflavones on breast or prostate cell proliferation have not been investigated so far. The nature of the physiological metabolites should yet be taken into consideration, because the biological properties of conjugated metabolites have already been shown to differ from those of the corresponding aglycones. The affinity of isoflavone glucuronides for ERs has been reported to be 10-40 times lower than that of the aglycones ${ }^{(80)}$. Furthermore, sulfation of isoflavones was shown to decrease their antioxidant activity and their effect on platelet aggregation, inflammation, cell adhesion and chemotaxis ${ }^{(81,82)}$. Tumour cell lines may have lost some membrane carriers, which would limit the uptake of anionic metabolites such as glucuronides or sulfates by the cells. For example, MCF-7 and T47D cells do not express the OATP-B carrier which is normally expressed in the mammary gland and transports a wide range of sulfated and glucuronidated conjugates of endogenous and exogenous compounds ${ }^{(83)}$. Thus, exposure to the same isoflavone concentration could result in quite different intracellular concentrations of isoflavone metabolites depending on the cell type used. To facilitate comparisons between in vitro studies, as well as extrapolation to the in vivo setting, information on intracellular concentrations of isoflavone metabolites should be provided in future studies on cultured cells. Another limit of in vitro studies is that they rarely used non-tumourigenic cells. Even if tumourigenic cell lines are of great interest to study specific signalling or metabolic pathways or to assess the potential therapeutic effects of isoflavones, these highly modified cells are not the best models to investigate the preventive effects of isoflavones.

\section{Mechanisms of action}

Although many studies have been conducted to understand the effects of soy isoflavones on breast and prostate cancer, available data are inconsistent and the mechanisms of action are still not entirely elucidated. Studies on animal and cellular models have firmly established that isoflavones are active compounds, showing quite variable effects depending on the dose, the form of administration, or the timing and duration of exposure. Serious concerns were raised about a possible estrogen-like detrimental effect of genistein through growth stimulation of pre-existing estrogen-sensitive mammary tumours. In the present state of our knowledge, the increasing isoflavone self-supplementation should be considered with caution until the mechanisms of action of isoflavones are better understood.

As questioned in the titles of S. Barnes, "Isoflavones = phytoestrogens and what else?", (84), or M. McCarty "Isoflavones made simple - Genistein's agonist activity for the beta-type estrogen receptor mediates their health benefits"(85), a largely debated issue is to establish whether isoflavones only act through their phytoestrogenic properties or whether ER-independent mechanisms of action may also play a role. Isoflavones have been reported to modulate steroid biosynthesis, transport and metabolism, as well as carcinogen activation and detoxification, to inhibit cell proliferation induced by growth factors, to induce cell cycle arrest or apoptosis, to favour cell differentiation, to reduce oxidative stress or to inhibit angiogenesis, cell invasiveness and metastasis ${ }^{(3,86)}$. They may act through modulation of cell signalling (direct binding to nuclear receptors, modification of the phosphorylation state of some signal transduction proteins), regulation of gene expression and/or specific inhibition of some key enzyme activities. 
The mechanisms of action of isoflavones are reviewed here in the context of breast and prostate cancer. Table 1 summarizes the most relevant studies that have been published for each putative mechanism of action and notifies whether in vivo data exist or whether the mechanism has only been observed in vitro. In vitro studies using isoflavone concentrations up to $10 \mu \mathrm{M}$ have been distinguished from studies using higher pharmacological concentrations.

The major focus in isoflavone research so far lies on the modulation of steroid hormone receptor signalling. Estrogens regulate many physiological processes in hormone-dependent tissues, including cell growth and differentiation, apoptosis and tissue-specific gene regulation, but also influence the pathological processes of hormone-dependent diseases, such as breast and prostate cancers. The biological actions of estrogens are mediated by the binding to one of the two specific nuclear receptors, $\mathrm{ER} \alpha$ and $\mathrm{ER} \beta^{(87)}$, which can induce gene transcription of estrogen-responsive target genes. A general hypothesis is that estrogens acting via ER $\alpha$ exert strong proliferation stimulatory effects while those interacting with ER $\beta$ tend to reduce this stimulation. Furthermore, ER $\beta$ has been shown to repress ER $\alpha$-controlled transcription ${ }^{(88,89)}$. Cell response would therefore depend on the balance between ER $\alpha$ and ER $\beta$ expression levels within a given cell type. This balance is altered in favour of ER $\alpha$ during tumour progression ${ }^{(90)}$, emphasizing the protective role of ER $\beta$ signalling and the usefulness of ER $\beta$-selective agonists in cancer prevention.

Eight in vitro and in vivo studies consistently reported a downregulation of ER $\alpha$ and an upregulation of ER $\beta$ mRNA and protein levels by genistein at $1-10 \mu \mathrm{M}$ in breast cancer cells ${ }^{(91-93)}$. A decrease in $\mathrm{ER} \alpha$ protein expression was also observed in mammary tumours of Sprague-Dawley rats after consumption of a soy extract ${ }^{(94)}$. In the dorsolateral prostate of rats and mice, exposure to dietary genistein $(\geq 25 \mathrm{ppm}$ for rats; $500 \mu \mathrm{g} / \mathrm{g}$ bw for mice) resulted in a downregulation of $\mathrm{ER} \alpha$ and ER $\beta$ mRNA and protein expression ${ }^{(95-97)}$.

Activation of ERs is an established effect of isoflavones that has been documented in the low nanomolar range, concentrations commonly achieved at nutritional levels of soy isoflavone intake. It has been shown in vitro that genistein has an agonist activity for both ER subtypes, but its affinity for ER $\beta$ is considerably greater than for $\mathrm{ER} \alpha$, with binding affinities of $8.4 \mathrm{nM}$ and $145 \mathrm{nM}$, respectively ${ }^{(98,99)}$. For daidzein, the corresponding values are $100 \mathrm{nM}$ and $420 \mathrm{~nm}$, indicating a much lower affinity for these receptors ${ }^{(98,99)}$. The transactivating functions of ER $\alpha$ and ER $\beta$ are mediated by two transcription activation functions (AF) located in the ligand-binding domain, AF-1 (N-terminal) and AF-2 (C-terminal). AF-1 is very active in $\mathrm{ER} \alpha$ on a variety of estrogen-responsive promoters, but minimal in ER $\beta$, whereas AF-2-mediated transcriptional activities of ERs are dependent on recruitment and interactions with cofactor proteins (coactivators and corepressors) to estrogen-responsive promoters ${ }^{(100)}$. The conformational change of the AF-2 transactivation helix induced by the formation of the ER $\beta$-genistein complex is closer to that induced by ER antagonists than by ER agonists and could therefore account for the partial agonistic behaviour of genistein ${ }^{(101)}$. The higher affinity of isoflavones for ER $\beta$ is paralleled by their ability to activate transcription with ER $\beta$ at lower concentrations than with $\mathrm{ER} \alpha^{(102)}$. Genistein, daidzein and equol were reported to increase the binding rate of ERs to estrogen responsive elements (ERE), with a more prominent effect on $E R \beta$ than ER $\alpha$. The concentrations of genistein, daidzein and equol which would increase this binding rate by $50 \%$ were determined to be $30 \mathrm{nM}, 350 \mathrm{nM}$ and $400 \mathrm{nM}$ for $\mathrm{ER} \beta$ and $15 \mu \mathrm{M},>300 \mu \mathrm{M}$ and $3.5 \mu \mathrm{M}$ for ER $\alpha$, respectively ${ }^{(103)}$.

The activation of ERs by isoflavones subsequently lead to a modulation of the expression of their target genes, and thus, to a modulation of cellular processes such as proliferation and apoptosis. Well-known target genes for the ERs are PR, pS2, bcl-2 and cyclin $\mathrm{D} 1^{(104,105)}$. PR mRNA and protein levels were shown to be upregulated by isoflavones in the majority of the in vitro and in vivo studies. In MCF-7 cells, an upregulation was observed with $1-10 \mu \mathrm{M}$ genistein ${ }^{(106)}$, and in premenopausal cynomolgus macaques and ovariectomised athymic nude mice implanted with MCF-7 cells, the doses ranged between 240 and $750 \mathrm{ppm}$ in the diet ${ }^{(66,107)}$. In contrast, a natural soy extract $(0.7 \%$ in the diet), containing $12 \%$ isoflavones and $35 \%$ saponins, decreased PR protein expression in mammary tumours of female Sprague-Dawley rats ${ }^{(94)}$. Furthermore, soy isoflavones stimulated the expression of the ER target gene pS2 in breast cells, as shown in twelve in vivo and in vitro studies. As for the modulation of $\mathrm{PR}$, low isoflavone concentrations (between 0.001 and $10 \mu \mathrm{M}$ ) were effective in vitro in MCF-7 cancer cells ${ }^{(106,108,109)}$, whereas in vivo doses above $500 \mathrm{ppm}$ in the diet in mouse xenograft models or $45 \mathrm{mg}$ daily in premenopausal women were used ${ }^{(55,66,110)}$. Only one in vivo study reported a converse decrease in mRNA expression of $\mathrm{pS} 2$ in premenopausal cynomolgus macaques after administration of $240 \mathrm{ppm}$ isoflavones in combination with $0.09 \mathrm{mg} / \mathrm{g}$ estradiol $^{(107)}$. Other ER target genes such as bcl-2 and cyclin D1 were also significantly increased in breast cells after genistein treatment. At $1 \mu \mathrm{M}$, it increased bcl-2 mRNA expression in MCF-7 cells ${ }^{(111,112)}$. Moreover, $750 \mathrm{ppm}$ genistein in the diet increased cyclin D1 mRNA expression in a mouse xenograft model ${ }^{(66)}$. Increased transcriptional and translational levels of the aforementioned estrogenresponsive target genes rather suggest estrogen-agonistic activities of isoflavones in breast cancer cells.

Since the androgen receptor (AR) pathway plays a pivotal role in prostate cell growth, differentiation and function, agents that minimise or eliminate AR transactivation are considered useful to prevent and treat prostate cancer. Although genistein does not seem to act as a ligand for $\mathrm{AR}^{(113,114)}$, it has been shown to exert anti-androgenic effects in prostate cells, and to downregulate the expression and secretion of the typical androgen-responsive gene PSA ${ }^{(113,115)}$. The mechanisms underlying isoflavone anti-androgenic effects are still not entirely elucidated. In more than seven in vitro and in vivo studies, a decrease in $\mathrm{AR}$ expression at mRNA and protein levels was detected in prostate cells exposed to low isoflavone concentrations $(0 \cdot 1-1 \mu \mathrm{M}$ in vitro; $250 \mathrm{ppm}$ in diet in vivo $)^{(96,113,116)}$. Long-term soy protein isolate consumption also lowered AR expression in prostate of men with high prostate cancer risk ${ }^{(117)}$. Isoflavones may also decrease androgen levels ${ }^{(118,119)}$. Moreover, a direct binding of DHT by equol has been reported in vitro, as well as a stimulation of testosterone inactivation through intracellular glucuronidation by biochanin $\mathrm{A}^{(120,121)}$. Interestingly, Bektic et al. demonstrated with the use of a pure anti-estrogen that the downregulation of the AR was mediated by ER $\beta$ in $\mathrm{LNCaP}$ cells. A cross-talk between ER and AR was also described by 


\begin{tabular}{|c|c|c|c|c|c|c|}
\hline Mechanism & Prostate & Breast & References & $\begin{array}{l}\text { Demonstrated } \\
\text { in vivo }\end{array}$ & $\begin{array}{l}\text { Demonstrated } \\
\text { in vitro with } \\
\text { physiological } \\
\text { doses }\end{array}$ & $\begin{array}{l}\text { Demonstrated } \\
\text { in vitro with } \\
\text { supra-physio- } \\
\text { logical doses }\end{array}$ \\
\hline \multicolumn{7}{|l|}{$E R$ and $A R$ pathway } \\
\hline \multirow[t]{3}{*}{$\begin{array}{l}\text { ER mRNA and protein } \\
\text { expression }\end{array}$} & $\begin{array}{l}\text { Downregulation of } \mathrm{ER} \alpha \mathrm{mRNA} \text { in pros- } \\
\text { tate of rats fed Ge ( } 250 \mathrm{ppm} \text { from } \\
\text { conception to day } 70 \text {, or } 250-\end{array}$ & $\begin{array}{l}\text { Downregulation of ER } \alpha \text { mRNA levels } \\
\text { in MCF-7 breast cell lines exposed } \\
\text { to } 1-10 \mu \mathrm{M} \text { Ge }\end{array}$ & $\begin{array}{c}(91,92,95-97 \\
106,184)\end{array}$ & $P$ & B & \\
\hline & $\begin{array}{l}1000 \mathrm{ppm} \text { from day } 56 \text { to day } 70) \\
\text { and in prostate of mice fed } \\
500 \mu \mathrm{g} \mathrm{Ge} / \mathrm{g} \mathrm{bw}\end{array}$ & $\begin{array}{l}\text { Decrease of ER } \alpha \text { protein expression } \\
\text { in mammary tumours of SD rats fed } \\
\text { a soy extract }(0.7 \% \text { in the diet) }\end{array}$ & $(94)$ & B & & \\
\hline & $\begin{array}{l}\text { Downregulation of ER } \beta \text { mRNA in pros- } \\
\text { tate of rats fed Ge ( } 250 \mathrm{ppm} \text { from } \\
\text { conception to day } 70 \text {, or } 250- \\
1000 \mathrm{ppm} \text { from day } 56 \text { to day } 70)\end{array}$ & $\begin{array}{l}\text { Upregulation of ER } \beta \text { mRNA levels in } \\
\text { breast cell lines exposed to } \\
1-10 \mu \mathrm{M} \mathrm{Ge}\end{array}$ & $(92,93,95,96)$ & $P$ & B & \\
\hline \multirow[t]{3}{*}{$\begin{array}{l}\text { AR mRNA and protein } \\
\text { expression }\end{array}$} & $\begin{array}{l}\text { Soy protein isolate consumption } \\
\text { ( } 107 \mathrm{mg} / \mathrm{d} \text { isoflavones) for } 6 \mathrm{mo} \\
\text { lowered AR but not ER } \beta \text { protein } \\
\text { expression levels in prostate of men } \\
\text { at high prostate cancer risk }\end{array}$ & & (117) & $P$ & & \\
\hline & $\begin{array}{l}\text { Downregulation of AR mRNA in pros- } \\
\text { tate of rats fed Ge ( } 250 \mathrm{ppm} \text { from } \\
\text { conception to day } 70 \text {, or } 250- \\
1000 \mathrm{ppm} \text { from day } 56 \text { to day } 70 \text { ) or } \\
\text { a phytoestrogen-rich diet ( } 600 \mathrm{ppm}) \text {; } \\
\text { no effect of Ge (250 ppm in diet) on } \\
\text { AR protein level in TRAMP mice } \\
\text { prostate }\end{array}$ & & $(96,180,263)$ & $P$ & & \\
\hline & $\begin{array}{l}\text { Downregulation of } A R \text { at the mRNA } \\
\text { and protein level in LNCaP cells } \\
\text { exposed to Ge }(0 \cdot 1-1 \mu \mathrm{M}) \text {; this } \\
\text { effect was abolished by the pure } \\
\text { antiestrogen ICl164 } 384 \text {, suggesting } \\
\text { an action via ER } \beta \text {. Da (up to } 50 \mu \mathrm{M} \text { ) } \\
\text { had no effect }\end{array}$ & & $(113,116)$ & & $\mathrm{P}$ & \\
\hline \multirow[t]{3}{*}{$\begin{array}{l}\text { ER target gene } \\
\text { expression (PR, pS2, } \\
\text { cyclin D1, bcl-2) }\end{array}$} & $\begin{array}{l}\text { Downregulation of PR protein } \\
\text { expression in the prostate of } \\
\text { C57BL/6 mice fed with } 500 \mu \mathrm{g} \mathrm{Ge} / \mathrm{g} \\
\text { bw }\end{array}$ & $\begin{array}{l}\text { Upregulation of PR mRNA and protein } \\
\text { expression by Ge }(1-10 \mu \mathrm{m} \text { in } \\
\text { MCF-7 cells; } 240-750 \mathrm{ppm} \text { in diet in } \\
\text { premenopausal cynomolgus maca- } \\
\text { ques and ovariectomized athymic } \\
\text { nude mice implanted with MCF-7 } \\
\text { cells) }\end{array}$ & $\begin{array}{l}(66,97,106 \\
107)\end{array}$ & $B, P$ & B & \\
\hline & & $\begin{array}{l}\text { Upregulation of pS2 mRNA and pro- } \\
\text { tein expression by Ge (0.001-10 } \mu \mathrm{M} \\
\text { in MCF-7 cells; } 500 \mathrm{ppm} \text { in diet in } \\
\text { ovariectomized athymic nude mice } \\
\text { implanted with MCF-7 cells) }\end{array}$ & $\begin{array}{c}(55,66,106 \\
108-110)\end{array}$ & B & B & \\
\hline & & $\begin{array}{l}\text { Upregulation of pS2 protein level in } \\
\text { nipple aspirate fluid of premenopau- } \\
\text { sal women supplemented with iso- } \\
\text { flavones ( } 45 \mathrm{mg} / \mathrm{d} \text { for } 14 \mathrm{~d} \text { ) }\end{array}$ & (110) & B & & \\
\hline
\end{tabular}


Androgen-stimulated transcription (androgen responsive genes promote prostate cancer

development and progression)

Synthesis and metabolism of steroids $17 \beta$-Hydroxysteroid dehydrogenase

$3 \beta$-Hydroxysteroid

dehydrogenase

Aromatase
Ge does not function as a ligand agonist for AR in either PC3 or LNCaP cells; no effect of $\mathrm{Ge}(1 \mu \mathrm{M})$ was detected on the activation of AR-dependent transciption in reporter gene assays Ge $(10 \mu \mathrm{M})$ decreased AR binding to ARE, thereby inhibited transcription of androgen-responsive genes such as PSA in LNCaP cells

Downregulation of PSA mRNA level in LNCaP cells exposed to $\mathrm{Ge}$ $(1-5 \mu \mathrm{M}) ; \mathrm{Ge}$ (10 nM) dose-dependently decreased PSA secretion in both androgen-treated and

untreated $\mathrm{LNCaP}$ cells (unknown

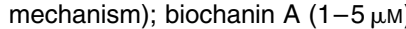
significantly decreased testosterone-stimulated release of PSA by LNCaP cells through upregulation of UDPGT and intracellular glucuronidation of testosteron

Ge $(10 \mu \mathrm{M})$ enhanced AR-driven gen (10prion (agoest R1881) thene expression (agonist Ris81) through activalion of the Ras signalling pathway in PC3 cells, as shown by the use of the specific

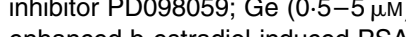
enhanced b-estradiol-induced PSA LNCaP cells

Inhibition of enzyme activity by $1-10 \mu \mathrm{M}$ Ge and Da in several in vitro models, not investigated in prostate cells

Inhibition of enzyme activity by $1-10 \mu \mathrm{M}$ Ge and Da in several in vitro models, not investigated in prostate and breast cells Inhibition of human aromatase in vitro by $G e$ at high doses $\left(K_{i}=123 \mu \mathrm{M}\right)$, Induction of cyclin D1 mRNA expression in a xenograft mice model by $\mathrm{Ge}(750 \mathrm{ppm})$

Induction of bcl-2 mRNA expression in MCF-7 cells exposed to Ge

$(111,112)$

$(1-10 \mu \mathrm{M})$

$(113,114)$

$(113,115,121)$

$(114,116)$

Inhibition of enzyme activity by $1 \mu \mathrm{M}$ Ge in T47D breast cancer cells 
Mechanism

Prostate

Breast

emonstrated

ysiologica

supra-physio-

$5 \alpha$-Reductase activity

Inhibition of type $25 \alpha$-reductase

activity by $\mathrm{Da}$ and $\mathrm{Ge}\left(\mathrm{IC}_{50}=7 \mu \mathrm{M}\right.$

and $\mathrm{IC}_{50}=20 \mu \mathrm{M}$ ) in vitro: not chan

and $\mathrm{I}_{50}$ Da

ged in rats fed isollavone-rich diet

(600 ppin) for 5 wa

$20 \mu \mathrm{M}$ inhibited $5 \alpha$-reductase activity

$(20 \%)$ in rat prostate tissue hom-

ogenates

Steroid sulfotransferase and sulfatase

tribition of hepatic estrogen sulfo-

transferase by $\mathrm{Ge}(0.5 \mu \mathrm{M})$ and

equation $(0.4 \mu \mathrm{M})$ in vitro; inhibition

of steroid sulfatase by Da-sulfat

$\left(\mathrm{IC}_{50}=6 \mu \mathrm{M}\right)$ and Da-disulfate

$\left(\mathrm{IC}_{50}<1.5 \mu \mathrm{M}\right)$ in vitro or in hamster

liver extracts, not investigated in

prostate and breast cells

Estrogen levels

Ovarian cycle length

Stimulation of hepatic

synthesis and secretion

of SHBG
References

$(118,265)$

doses

logical doses
Inconsistent effects of soy or isoflavone consumption on circulating hormone profiles in women. $2 \mathrm{mg}$ isoflavones $/ \mathrm{kg}$ bw/d for 93 days decreased estrone sulfate plasma level in postmenopausal women.

$40 \mathrm{mg}$ Ge/d for 12 weeks decreased

serum-free estradiol and estrone in

premenopausal women Other

premenopausal women. Other
studies did not find significant

changes in circulating sex steroid

hormes in circulating sex steroid

hormones. equol-producing

mop

reduced estrone and estrone

plasma levels after isoflavone

consumption $(0.15,1,2 \mathrm{mg} / \mathrm{d})$ in

comparison to non-producers

Trend toward increased cycle lengt

(32-200 mg isoflavones/d), but

inconsistent results; mean follicular

phase increased with 12-week sup-

plementation of $40 \mathrm{mg} \mathrm{Ge} / \mathrm{d}$ in

young women

Observed in vitro in HepG2 cells

exposed to $\geq 5 \mu \mathrm{M} \mathrm{Ge}$; in vivo studies

showed an increasing effect in preme-

nopausal women determined as

'equol-producers' after consumption of

$0.15,1$ or $2 \mathrm{mg}$ isoflavones/d and in

postmenopausal women after con-

sumption of $30 \mathrm{~g}$ soy milk $(=69 \mathrm{mg}$

isoflavones)/d for 10 weeks; $2 \mathrm{mg}$

isoflavones/kg bw/d for 93 days)
$(31,130,137)$

B

$(130-132)$

B 
Table 1. Continued

changes in circulating sex steroid

$$
\text { hormones }
$$

Eq specifically binds circulating and intracellular DHT with an apparent $\mathrm{K}_{\mathrm{d}}$ of $1.32 \mathrm{~nm}$ and prevent DHT's biological actions

Hypothalamic-pituitarytesticular (HPT) axis

Cell cycle control and apoptosis Cell cycle arres

Downregulation of cyclin B expression; inhibition

of cdc2 activity

Upregulation of cyclin-

dependent inhibitors

dependent inhibitor
(p21 ${ }^{\text {WAF1 }} ;$ p27

Induction of apoptosis

o significant differences in plasma

$\mathrm{LH}$ in rats fed a phytoestrogen-rich diet $(600 \mathrm{ppm})$ for 5 weeks. Lack of significant effects of soy protein isolate supplementation on serum LH

in men; 2 week-supplementatio

with clover phytoestrogens

$(240 \mathrm{mg} / \mathrm{d})$ increased serum $\mathrm{LH}$ and

modestly decreased serum testos-

terone concentrations

in men with prostate cancer and

induced testicular resistance to $\mathrm{LH}$

G1 or G2/M arrest only observed in vitro at high Ge concentrations $(20-60 \mu \mathrm{M})$; not observed at $10 \mu \mathrm{M}$ Ge in LNCaP cells

G2/M arrest observed with 5-10 $\mu \mathrm{M}$ Ge in breast cancer cell lines and $\geq 15 \mu \mathrm{M}$ in non-neoplastic breast cells

Observed in MCF-10F, MCF-7 and MDA-MB-231 cells exposed to high MDA-MB-231 cels exposed to high observed in mammary gland of $\mathrm{M}$ ) fed $\mathrm{Ge}$ or soy protin ind

$(0.5 \mathrm{mg} / \mathrm{kg}$ bw) and in MCF-7, MDAMB-231 and AU565 cells exposed to $\mathrm{Ge}(\geq 1 \mu \mathrm{M})$

to Ge $(\geq 1 \mu \mathrm{M})$ mary

Observed in mammary gland of

Observed in PC3 and LNCaP cells exposed to high concentration of $\mathrm{Ge}(>20-50 \mu \mathrm{M})$
$250 \mathrm{ppm}$ Ge $\mathrm{pr}$.

vones in diet); observed in MCF-7

and MDA-MB-231 cells in MCP- 7

high Ge concentration $(\geq 25 \mu \mathrm{M})$
$(118,269,270)$

(147-152)

$(148,149,152,155$,

$157,164,271)$

$(148,149,155$,

$160-164)$

$(3,86,112,160$

$163,271)$

P, B 
Mechanism

Downregulation of antiapoptotic Bcl-2, Bcl-x and uprotic Bcl-2, $\mathrm{Bcl}-\mathrm{X}$ and upregulation of pro
tic Bax, Bak, Bok expression exposed to than $40 \mu \mathrm{M}$

Inhibition of proteasome activity (which plays essential role in promoting ting tumour cells from apoptosis)

\section{Angiogenesis}

Microvessel density in tumours

Invasion and metastasis

Cell adhesion and migration

Matrigel invasion

Matrix metalloproteinases (MMP)

Osteopontin

Inhibition of chymotrypsin-like activity $(-30 \%)$ of purified proteasome $\mathrm{Ge}$, but much higher Ge concentration needed to inhibit proteasom in intact LNCaP cells $\left(\mathrm{IC}_{50}=70 \mu \mathrm{M}\right)$

Reduced vessel density in SCID mice inoculated with LNCaP cells and fed of soy phytochemical concentrate (415 ppm, 756 ppm, 2120 ppm isoflavones)

No effect on VEGF and VEGFR expression in prostate of TRAMP
Prostate

Breast

Not modified in prostate cancer cells from LNCaP cell extracts by $1 \mu \mathrm{M}$ diets supplemented with three levels Observed in mammary gland of rats
fed Ge or soy protein isolate (250 ppm Ge or 394 ppm ise vones in diet) and in MDA-MB-23 vones in diet) and in MDA-MB-231 $\mathrm{Ge}(\geq 5 \mu \mathrm{M})$ Inhibition of chymotrypsin-like activity $(-30 \%)$ of purified proteasome from MCF-7 cell extracts by $1 \mu \mathrm{M}$ $\mathrm{Ge}$, but much higher Ge concentration needed to inhibit the proteasome in intact MCF-7 cells $\left(\mathrm{IC}_{50}=65 \mu \mathrm{M}\right)$

Reduced vessel density and decreased protein levels of VEGF and TGFB in tumours and serum from nude mice implanted with MDA-MB-231 and MCF-7 cells and treated by s.c. injections of $\mathrm{Ge}$ $(0.1-0.5 \mathrm{mg} / \mathrm{kg} \mathrm{bw})$

$(3,112,148,160$

doses

logical doses mice fed 250 ppm Ge

$\mathrm{Ge}(\geq 10 \mu \mathrm{M})$ and $\mathrm{Da}(100 \mu \mathrm{M})$ suppressed cell migration and suppressed cell migration and
cell adhesion of highly invasive MDA-MB-231 cells

Reduction of the invasive potential and upregulation of KAl1 mRNA and protein levels in TRAMP-C2 prostate cancer cells exposed to $5 \mu \mathrm{M}$ Ge; induction of PC-3 and DU 145 cell invasion through Matrigel by plasminogen is counteracted by Ge (dose unknown)

Inhibition of MMP-2 expression in PC3 and LNCaP cells by $\mathrm{Ge}(>18 \mu \mathrm{M})$; Ge (>10 nM) inhibited TGF- $\beta$ mediated induction of MMP-2 in six cell lines including normal, early cancer and established cancer prostate cell lines, possibly through inhibition of p38 MAPK

$\mathrm{Ge}(250$ or $500 \mathrm{mg} \mathrm{Ge} / \mathrm{kg}$ bw) reduced OPN mRNA levels in TRAMP mice prostates displaying advanced prostate cancer upregulation of TIMP-1 mRNA
Induction of MDA-MB-231 cells invasion through Matrigel by reversed by $\mathrm{Ge}(10 \mu \mathrm{M})$

Downregulation of MMP-9 and expression in tumours from nude mice implanted with MDA-MB-231 or MCF-7 cells and treated by s.c. injections of $\mathrm{Ge}(0.1-0.5 \mathrm{mg} / \mathrm{kg} \mathrm{bw})$
$\mathrm{P}, \mathrm{B}$ 
Table 1. Continued

Mechanism

Prostate

Breast

Regulation of cell signalling pathways

Growth factors

Downregulation of EGFR expression in rat and TRAMP mice prostate with $250-1000 \mathrm{ppm}$ Ge in the diet; Not seen in $\mathrm{LNCaP}$ cells

Inhibition of EGF-stimulated growth of LNCaP and DU145 cells by Ge and $\mathrm{Da}(15-60 \mu \mathrm{M})$, without inhibition of EGFR autophosphorylation

IGF-1 signalling

Downregulation of IGF-1R but not of GF-1 in TRAMP mice fed $250 \mathrm{ppm}$ genistein

Inhibition of IGF-1 stimulated proliferation of rat prostatic cancer cells by $\mathrm{Ge}(10 \mu \mathrm{M})$

Positive association between soy protein intake (food frequency questionnaire) and serum IGF-1 levels in Asian men

$40 \mathrm{~g}$ soy protein for 3 months increased IGF-1 serum levels stronger than milk protein; $83 \mathrm{mg} / \mathrm{d}$ soy isoflavone for $12 \mathrm{mo}$ did not modulate serum IGF in old men; 3-6mosupplementation widh 100

serum levels of IGF-1 or IGFBP-3 levels in men with prostate cancer

Decreased serum IGF-1 levels in Han:SPRD-cy rats fed a soy protein-based diet for 6 weeks and in mice after supplementation with soy protein isolate ( $20 \%$ in diet) and soy phytochemical concentrate ( $1 \%$ in diet)

Initial upregulation of EGFR protein in mammary gland of young rats, pre-

(179-183)

pubertally treated with $\mathrm{Ge}(250 \mathrm{ppm}$

in diet or $500 \mu \mathrm{g} / \mathrm{g} \mathrm{bw}$ ) and sub-

sequent downregulation of EGFR in

mammary gland (stimulation of early differentiation)

Inibition of DNA synthesis by $0.1 \mu M$

Ge in presence of $1 \mathrm{ng} / \mathrm{mlEGF}$

induction of DNA synthesis by

$1-10 \mu \mathrm{M}$ Ge in presence of $1 \mathrm{ng} / \mathrm{ml}$ EGF in breast cancer cells

regulation of IGF-1R, IRS-1 mRNA and protein expression in MCF-7 cells by $1 \mu \mathrm{M} \mathrm{Ge}$

Induction of IGF-1-induced DNA synthesis by $0.1-10 \mu \mathrm{M} G$ e; inhibition of GF-I-stimulated proliferation of MCF-7 cells by $\mathrm{Ge}(>25 \mu \mathrm{M})$

No significant association between soy product and soy isoflavone intake and serum IGF-1 in Asian premenopausal and European preand postmenopausal women

Increased IGF-I plasma levels after

$40 \mathrm{~g}$ soy protein intake for 3 months in postmenopausal women; $80 \mathrm{mg}$ total phytoestrogens daily increa IGF-I and IGFBP-3 dasma increased after 1 week in healthy women; isoflave is for 3 months ide $(1 \mathrm{mg} / \mathrm{kg}$ b and IGFBP- 3 serum levels in $p$ remenoparemovent diet $(2 m$

(d) +d) for 3 months decreased IGFand IGFBP-3 serum levels in posmenopausal women 
Akt and $N F_{K} B$ pathways and their cross-talk

Akt pathway (activation promots cell

survival, by inactivation of

pro-apoptotic factors; also

regulates $\mathrm{NF}_{\kappa} \mathrm{B}$ pathway)

$\mathrm{NF} \kappa \mathrm{B}$ (control of cell growth, differentiation, apoptosis,

inflammation, stress

response)
Inhibition of Akt phosphorylation by $10 \mu \mathrm{M}$ Ge in DU145 cells

Inhibition of Akt kinase activity by $50 \mu \mathrm{M}$ Ge in non-stimulated PC3 cells, and abrogation of EGF-stimulated Akt activation

Incorporation of $\mathrm{Ge}$ in the diet $(250$ and $1000 \mathrm{ppm}$ ) of transgenic male TRAMP/FVB mice resulted in a drastic reduction of Akt activation, subsequent activation of GSK-3 $\beta$, culmt-trang in a dose-dependent post-transcriptional reduction in f the calnerin-1 complex via downregulation of snail-1

Induction of PTEN gene expression in $\mathrm{PC}-3$ and LNCaP cells by Ge

$(20 \mu \mathrm{M})$. Decreased expression of VEGF, ER $\alpha$ and ER $\beta$ genes may be via repression of Akt pathway by PTEN

Inhibition of IкB phosphorylation by Ge $(50 \mu \mathrm{M})$ in LNCaP and PC3 cells Inhibition of NFKB DNA-binding activity by $\mathrm{Ge}(>30 \mu \mathrm{M})$ in $\mathrm{LNCaP}$ and $\mathrm{PC} 3$ cells

Ge $(>30 \mu \mathrm{M})$ abrogated NFKB activation by DNA damaging agents $\left(\mathrm{H}_{2} \mathrm{O}_{2}\right.$ and TNF- $\left.\alpha\right)$ in LNCaP and PC3 cells

\section{Inhibition of Akt phosphorylation in MCF-7 cells exposed to Ge $(>1 \mu \mathrm{M})$ Decrease in phosphorylated Akt1 and total Akt1 in non-stimulated MDA- MB-231 cells exposed to $\mathrm{Ge}$ $(30 \mu \mathrm{M})$; abrogation of EGF-stimu- lated Akt activation by $\mathrm{Ge}(50 \mu \mathrm{M})$ in MDA-MB-231 cells}

Induction of PTEN protein expression in $\mathrm{SD}$ rats fed $\mathrm{Ge}$ or soy protein isolate $(250 \mathrm{ppm}$ Ge or $394 \mathrm{ppm}$ isoflavones in diet) and in MCF-7 cells exposed to $\mathrm{Ge}(>0.1 \mathrm{~nm})$

Induction of $\mathrm{I}_{\mathrm{K}} \mathrm{B}$ protein expression in MCF-7 cells by $100 \mu \mathrm{M}$ Ge Inhibition of NFKB DNA-binding activity in MDA-MB-231 breast cancer cells exposed to $\mathrm{Ge}(>30 \mu \mathrm{M})$ Ge $(50 \mu \mathrm{M})$ abrogated EGF- and AKTinduced $\mathrm{NF} K \mathrm{~B}$ activation in MDAMB-231 breast cancer cells

Inhibition of arachidonic acid-stimulated NFKB mRNA expression by Ge $(2.5 \mu \mathrm{M})$ in MDA-MB-231 cells $0.5 \mu \mathrm{M}$ Ge activated NFKB and elevated expression of $\mathrm{Mn}-\mathrm{SOD}$ through $\mathrm{Ge}(\geq 10 \mu \mathrm{M})$ and $\mathrm{Da}(100 \mu \mathrm{M})$ inhib$\mathrm{Ge}(\geq 10 \mu \mathrm{M})$ and $\mathrm{Da}(100 \mu \mathrm{M})$ inhib-
ited constitutively active transcription factors NFKB and AP-1 in highly invasive MDA-MB-231 cells 


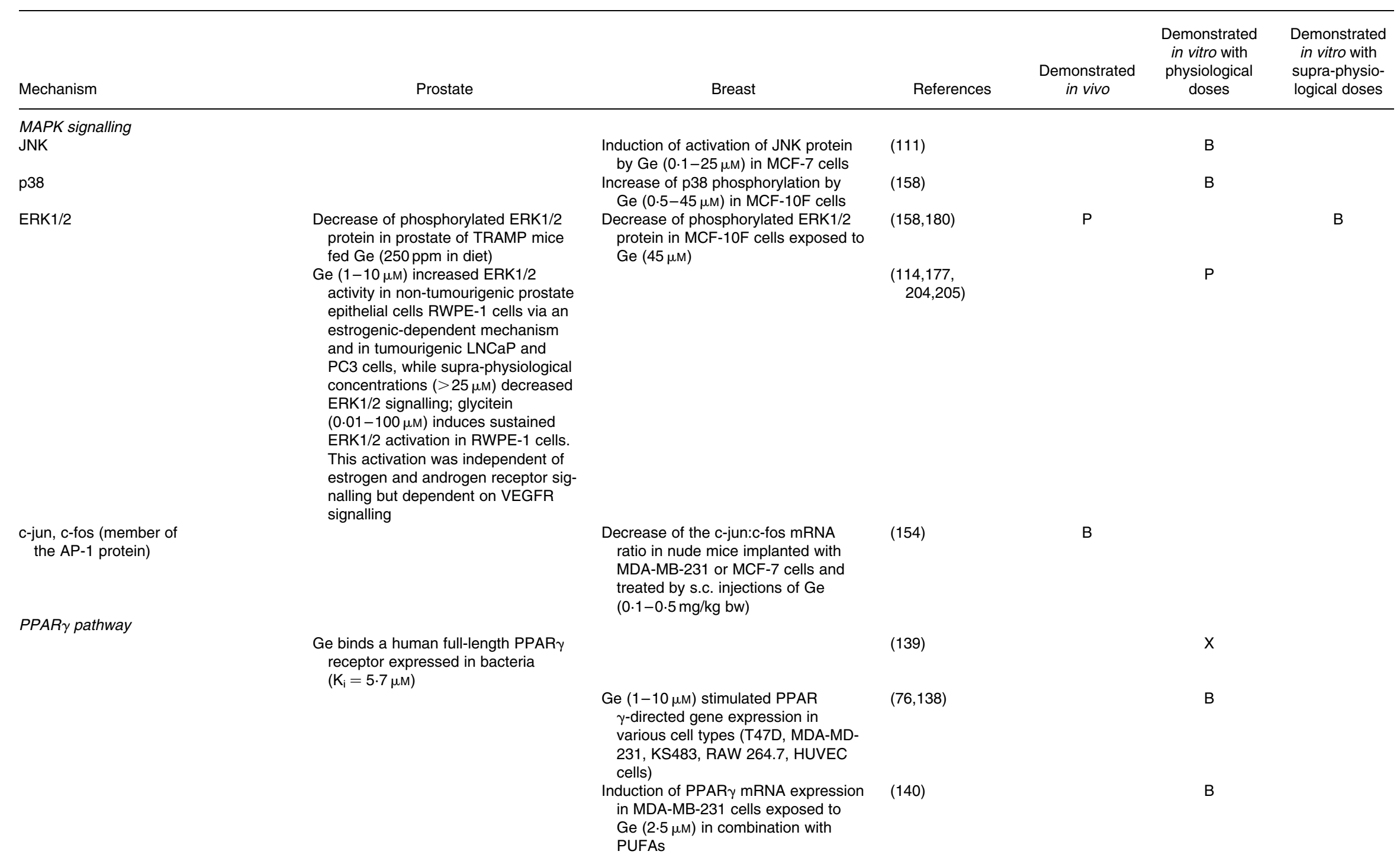


NS British Journal of Nutrition

Antioxidant activities

(prevention of oxidative

stress)

Free radical scavenging

Oxidative metabolites of genistein and daidzein, as well as genistein and equol inhibited in vitro formation of conjugated dienes and TBARS in copper-induced LDL oxidation

$\left(\mathrm{EC}_{50}<10 \mu \mathrm{M}\right)$, not investigated in

prostate and breast cells. Ge inhib-

ited TPA-stimulated $\mathrm{H}_{2} \mathrm{O}_{2}$ pro-

duction in human

polymorphonuclear leukocytes

$\left(\mathrm{IC}_{50}=14.8 \mu \mathrm{M}\right)$ and $\mathrm{HL}-60$ cells

$\left(\mathrm{C}_{50}=30.2 \mu \mathrm{M}\right) \mathrm{Ge}(>10 \mu \mathrm{M}) \mathrm{sca}$

veno

venged $\mathrm{H}_{2} \mathrm{O}_{2}$ in a cell-free system.

mation $201-10 \mu \mathrm{M})$ suppress

mation. $\mathrm{Ge}(0.1-10 \mu \mathrm{M})$ suppresses

TPA-mediated $\mathrm{H}_{2} \mathrm{O}_{2}$ formation in

mouse skin, not investigated in
prostate and breast cells

Antioxidant enzyme

regulation

pregulation of GPx mRNA

expression in $\mathrm{LNCaP}$ and $\mathrm{PC}-3$

cells exposed to $\mathrm{Ge}(100 \mu \mathrm{M})$

Upregulation by Ge of MT-1X mRNA

and protein expression $(1-30 \mu \mathrm{M})$,

GSR mRNA expression $(10-30 \mu \mathrm{M})$

and mGST-1 mRNA expression

$(30 \mu \mathrm{M})$ in LNCaP cells

Induction of Mn-SOD mRNA

expression in MCF-7 cells exposed to $0.5 \mu \mathrm{M} \mathrm{Ge}$

soflavone supplementation $(138 \mathrm{mg} / \mathrm{d})$

for 24 days increased $\mathrm{Cu} / \mathrm{Zn}$-SOD

activities in erythrocytes of breas

cancer survivors 
Phase II
Vitamin D metabolism

Synthesis of the antiproliferative and prodifferentiative metabolite 1,25 dihydroxy-vitamin D3

Inhibition of topoisomerase

(maintains DNA structure)

Induction of UDPGT activity in LNCaP cells exposed to $5 \mu \mathrm{M}$ Ge Inhibition of SULT1A1 activity in

human liver tissues by $\mathrm{Ge}$

$$
\left(\mathrm{IC}_{50}=2 \mu \mathrm{M}\right)
$$

Time- and concentration-dependent upregulation of BRCA1 and BRCA protein levels in $\mathrm{LNCaP}$ and DU145 cells exposed to $\mathrm{Ge}(0.5-7.5 \mu \mathrm{M})$

Telomerases

Downregulation of CYP24 and CYP27B1 expression in DU-145 cells exposed to $\mathrm{Ge}(>25 \mu \mathrm{M})$

Inhibition of topoisomerase II by Ge $(>20 \mu \mathrm{M})$ in vitro, not investigated in prostate and breast cells
$\left(\mathrm{K}_{\mathrm{i}}=15.4 \mu \mathrm{M}\right.$ and $\mathrm{Ki}=0.7 \mu \mathrm{M}$,

duction of GSTP1 mRNA, protein expression and enzyme activity in non-tumourigenic MCF-10A cells exposed to Ge $(1-30 \mu \mathrm{M})$

Induction of quinone reductase (QR) mRNA and protein expression in MDA-MB-231 and MCF-7 cells exposed to $10 \mu \mathrm{M} G$

Inhibition of $C O M T$ activity in cytosolic fractions of human mammay tisructions or human mam Induction of liver GPx, GR,

GST, GST, colon QR and colon UDPGT vones $(0.81 \mathrm{mg} / \mathrm{g}$ diet $)$ protein leve BRCA1 and BRCA cells exposed to $\mathrm{Ge}(0.5-1 \mu \mathrm{M})$

Upregulation of BRCA2 mRNA levels in ovariectomised rats fed isoflavone-formulated Soylife $(8 \mu \mathrm{g} / \mathrm{g} \mathrm{bw})$; upregulation of BRCA1 protein leveIs in rats fed Ge (1.25-3.3 $\mu \mathrm{g} / \mathrm{g} \mathrm{bw})$

Repression of hTERT transcriptional activity in PC3 and DU145 cells exposed to Ge $(50 \mu \mathrm{M})$ Ge $(100 \mu \mathrm{M})$
Increase of CYP27B1 mRNA, protein expression and enzyme activity in MCF-7 cells exposed to $50 \mu \mathrm{M}$ Ge

Significant reduction of telomere 
Davis et al. ${ }^{(116)}$, who reported that genistein $(0 \cdot 5-5 \mu \mathrm{M})$ enhanced $17 \beta$-estradiol-induced PSA expression in LNCaP cells. At a slightly higher concentration $(10 \mu \mathrm{M})$, genistein stimulated AR-driven gene expression through activation of the Raf-MEK-ERK signalling pathway in PC3 cells, again demonstrating the critical importance of the dose. It is noteworthy that daidzein, at concentrations up to $50 \mu \mathrm{M}$, did not modulate PSA or AR protein levels in $\mathrm{LNCaP}$ cells ${ }^{(116)}$.

Because steroid hormone levels influence the development of hormone-dependent cancers, the research also focused on the impact of isoflavones in the synthesis and metabolism of steroids. However, the potency of isoflavones to inhibit some key enzymes involved, such as 17 $\beta$-hydroxysteroid dehydrogenase, $3 \beta$-hydroxysteroid dehydrogenase, aromatase and $5 \alpha$-reductase, in humans is questionable. Although the inhibition of $17 \beta$-hydroxysteroid dehydrogenase, $3 \beta$-hydroxysteroid dehydrogenase and $5 \alpha$ reductase was observed at low doses of $1-10 \mu \mathrm{M}$, this was mostly shown in platelet microsomes or using isolated human enzymes ${ }^{(69,122-124)}$. Data for enzyme inhibition in breast and prostate cells are still limited. Makela et al. reported an inhibition of $17 \beta$-hydroxysteroid dehydrogenase with $1 \mu \mathrm{M}$ genistein in breast cancer cells ${ }^{(125)}$. In rat prostate homogenates an inhibition of $5 \alpha$ reductase activity was observed after treatment with $20 \mu \mathrm{M}$ genistein ${ }^{(126)}$. Genistein and equol at nanomolar concentrations also showed inhibition of steroid sulfotransferases in vitro, whereas daidzein sulfates at $1.5-6 \mu \mathrm{M}$ inhibited steroid sulfatase significantly ${ }^{(127-129)}$. Finally, a favourable reduction in serum hormone levels in women and men as well as the stimulation of SHBG and the prolongation of the menstrual cycle in women supplemented with soy isoflavones have been observed in some studies, even if results are still quite inconsistent ${ }^{(31,117-120,130-133)}$. It should be noticed that these mechanisms in women were highly dependent on factors such as the menopausal status, the level of endogenous estrogens, the intake of oral contraceptives and the gut microbial composition. In a postmenopausal primate model as well as in postmenopausal women isoflavone supplementation ( $129 \mathrm{mg} / 1800 \mathrm{kcal}$ and $2 \mathrm{mg} / \mathrm{kg}$ bw/d, respectively) decreased serum hormones such as estrone-sulfate, estrone, estradiol and increased urinary 2-hydroxyestrone levels as well as the urinary 2:16 $\alpha$-hydroxyestrone ratio $^{(134,135)}$. Furthermore, it was shown that isoflavones $(60,120$ and $240 \mathrm{mg} / \mathrm{d})$ lowered serum estrone and estradiol concentrations significantly in a high estradiol environment but not in a low estradiol environment in postmenopausal primates ${ }^{(107)}$. Studies in premenopausal women showed inconsistent results. While no changes in menstrual cycle length and serum hormones were observed after long-term intervention with high isoflavone doses $(50 \mathrm{mg} / \mathrm{d} \text { for } 2 \text { years or } 100 \mathrm{mg} / \mathrm{d} \text { for } 1 \text { year })^{(17,136)}$, a shortterm intervention of 12 weeks with $40 \mathrm{mg}$ genistein/d and of 93 days with 10, 64 and $128 \mathrm{mg}$ isoflavones/ $\mathrm{kg}$ bw/d increased menstrual cycle length and decreased serum free estradiol, estrone, DHEA-sulfate, follicle stimulating hormone (FSH) and luteinising hormone (LH) levels ${ }^{(130,137)}$. It was also demonstrated that gut microflora influenced serum hormone levels of premenopausal women, showing that equol-producers had lower serum hormone concentrations after isoflavone supplementation than non-producers ${ }^{(31)}$.

Recent in vitro studies suggest that isoflavones may also act through activation of other nuclear receptors than ER and AR.
Dang et al. showed for the first time in 2003 that genistein was able to bind a human full-length PPAR $\gamma$ receptor expressed in bacteria, with a $\mathrm{K}_{\mathrm{i}}$ of $5.7 \mu \mathrm{M}$, comparable to that of some known PPAR $y$ ligands ${ }^{(76)}$. Furthermore, genistein dose-dependently $(5-50 \mu \mathrm{M})$ stimulated PPAR $\gamma$-directed gene expression in T47D and MDA-MD-231 breast cancer cells and other cell types transfected with PPRE-luciferase construct and expression plasmids encoding human PPAR $\gamma^{(76,138)}$. A similar reporter assay and siRNA targeting approach confirmed the PPAR $\gamma$ agonist effect of genistein in HUVEC cells at a low physiological dose $(1 \mu \mathrm{M})^{(139)}$. Genistein $(2 \cdot 5 \mu \mathrm{M})$ in combination with polyunsaturated fatty acids also induced PPAR $\gamma$ mRNA expression in MDA-MB-231 cells ${ }^{(140)}$. PPAR $\gamma$ agonists are known to act as modulators of cell cycle and estrogenic actions, to inhibit the proliferation of cultured human breast and prostate cancer cells, and to modify breast epithelial gene expression leading to a more differentiated and less-malignant state ${ }^{(141-144)}$. Accumulating evidence also suggests that PPAR $\gamma$ may act as a tumour suppressor in prostate cancer. Phase II clinical trials using PPARy ligands have been recently carried out as novel therapy for advanced breast and prostate cancer patients $^{(143,145,146)}$. A balance between ER and PPARy activation, depending on the genistein concentration and the levels of ER and PPAR $\gamma$ in the tissue may thus explain some of the effects of isoflavones ${ }^{(145)}$

Isoflavones are capable of inhibiting proliferation by inducing G1 and/or G2/M cell cycle arrest in breast and prostate cancer cells ${ }^{(3,147,148)}$. While concentrations ranging between 5 and $10 \mu \mathrm{M}$ genistein inhibited cell cycle in breast cancer cell lines, pharmacological doses of $20-60 \mu \mathrm{M}$ were required to achieve the same effect in prostate cancer cells ${ }^{(147,149-152)}$. Progression in the cell cycle depends on the activity of a functional complex formed between cyclin B1 and the cyclin-dependent kinase (cdk) $\mathrm{Cdc} 2^{(99,153)}$. A significant downregulation of cyclin $\mathrm{B} 1$ and $\mathrm{Cdc} 2$ levels by genistein has been consistently observed in breast and prostate models in vitro, but only at high doses $(20-100 \mu \mathrm{M})^{(154-157)}$. In order to achieve the inhibition of $\mathrm{Cdc} 2$ protein expression, supra-physiological doses of genistein $(\geq 45 \mu \mathrm{M})$ were also required in non-tumour breast cells as well as in breast and prostate cancer cells ${ }^{(152,156)}$. In addition, progression to mitosis can be affected by the phosphorylation status of $\mathrm{Cdc} 2$ mediated by Wee-1 protein kinases ${ }^{(156)}$. Exposure of the non-tumorigenic breast cell line MCF-10F to $45 \mu \mathrm{M}$ genistein resulted in an increase in phosphorylated $\mathrm{Cdc} 2$ protein levels ${ }^{(158)}$, and in TRAMP C2 prostate cells an increase in protein expression of protein kinase Myt-1 was observed upon exposure to $50 \mu \mathrm{M}$ genistein ${ }^{(156)}$. In contrast, the other protein kinase Wee-1 was suppressed ${ }^{(156)}$. On the other hand, dephosphorylation of $\mathrm{Cdc} 2$ by the phosphatase $\mathrm{Cdc} 25 \mathrm{C}$ increases the kinase activity of the cyclin $\mathrm{B} 1-\mathrm{Cdc} 2$ complex in the $\mathrm{M}$ phase ${ }^{(159)}$. The group of Frey et al. demonstrated a significant downregulation of $\mathrm{Cdc} 25 \mathrm{C}$ protein expression using $50 \mu \mathrm{M}$ genistein in the non-tumorigenic breast cell line MCF$10 \mathrm{~F}^{(152)}$. In summary, the effect on cdc2 phosphorylation was only observed at high genistein concentrations.

Cell cycle progression is also affected by the levels of cdk inhibitors p2 $1^{\mathrm{WAF} 1}$ and $\mathrm{p} 27^{\mathrm{KIP} 1}$, which were significantly upregulated upon genistein supplementation in breast and prostate cells. Eleven in vivo and in vitro studies on breast cancer showed a genistein-induced upregulation of $\mathrm{p} 21^{\mathrm{WAF} 1}$ 
$(\geq 0.5 \mathrm{mg} / \mathrm{kg}$ bw in mouse xenograft model, $250 \mathrm{ppm}$ in the diet in Sprague-Dawley rats, $\geq 5 \mu \mathrm{M}$ in breast cell lines MCF-7, MDA-MB-231) and $\mathrm{p} 27^{\mathrm{KIP} 1} \mathrm{mRNA}$ and protein levels $(\geq 1 \mu \mathrm{M}$ in breast cell lines MCF-7, MDA-MB$231)^{(154,160-163)}$. In prostate cancer cells, an upregulation of $\mathrm{p} 21^{\mathrm{WAF} 1}$ and $\mathrm{p} 27^{\mathrm{KIP} 1} \mathrm{mRNA}$ and protein levels was consistently observed upon exposure to high concentrations of genistein $(20-60 \mu \mathrm{M})$, as summarised from eight in vitro studies $^{(149,155,164)}$.

In addition to the inhibition of cell proliferation, isoflavones can induce apoptosis in human breast and prostate cells at concentrations over $25 \mu \mathrm{M}$ and $20 \mu \mathrm{M}$, respectively ${ }^{(3,104)}$. One in vivo study reported isoflavone-induced apoptosis in mammary glands of Sprague-Dawley rats $(250 \mathrm{ppm}$ genistein or 394 ppm mixed isoflavones $)^{(163)}$. Pro-apoptotic proteins Bax, Bak and Bok were shown to be upregulated in breast cell culture models or rat mammary glands by genistein at respectively concentrations of $5 \mu \mathrm{M}, 25 \mu \mathrm{M}$ or $250 \mathrm{ppm}$ in the $\operatorname{diet}^{(112,160,163)}$, while anti-apoptotic proteins Bcl-2 and Bcl$\mathrm{x}_{\mathrm{L}}$ were downregulated at genistein concentrations $\geq 5 \mu \mathrm{M}$ in vitro (MDA-MB-231, 184-B5/HER) ${ }^{(112,160)}$. Data regarding apoptosis-associated proteins and their modulation by isoflavones in prostate cells are limited. However, it was shown by three different groups that genistein concentrations above $40 \mu \mathrm{M}$ were necessary to upregulate Bax and downregulate $\mathrm{Bcl}-\mathrm{x}_{\mathrm{L}}$ and $\mathrm{Bcl}-2$ in vitro $^{(148,165,166)}$. Furthermore, expression of cell cycle regulators such as p53, PTEN, $\mathrm{p} 21^{\mathrm{WAF} 1}$ and $\mathrm{p} 27^{\mathrm{KIP} 1}$, also involved in the apoptotic process, were modulated by isoflavones. The modulation of $\mathrm{p} 21^{\mathrm{WAF} 1}$ and $\mathrm{p} 27^{\mathrm{KIP} 1}$ has been described above. From two in vitro studies reporting p53 modulation in breast cancer and two studies (one in vivo, one in vitro) reporting p53 modulation in prostate cancer, it was shown that only high genistein concentrations $(\geq 25 \mu \mathrm{M})$ were able to increase this protein expression $^{(111,167)}$. In contrast, the tumour suppressor gene PTEN was upregulated after incubating MCF-7 cells with a very low concentration of $0.1 \mathrm{nM}$ genistein $^{(161)}$. In vivo, doses of $250 \mathrm{ppm}$ genistein or $394 \mathrm{ppm}$ mixed isoflavones were also reported to induce PTEN protein expression in the mammary gland ${ }^{(163)}$. An induction of PTEN gene expression by genistein $(20 \mu \mathrm{M})$ was similarly described for LNCaP and PC3 prostate cells ${ }^{(168)}$.

Inhibition of angiogenesis is another biological effect of isoflavones that has been reported in vivo in the context of breast and prostate cancer. Genistein $(0.1-0.5 \mathrm{mg} / \mathrm{kg}$ bw) or a soy phytochemical concentrate significantly reduced vessel density in breast and prostate mouse xenografts ${ }^{(147,154)}$. In highly invasive MDA-MB-231 breast cancer cells, $10 \mu \mathrm{M}$ genistein suppressed cell migration as well as cell adhesion $^{(169)}$. Furthermore, the invasive potential of several breast and prostate cancer cell lines was reduced by high physiological doses of genistein $(5-10 \mu \mathrm{M})^{(140,170,171)}$. The group of El Touny observed a genistein-induced upregulation of the metastasis suppressor Kangai-1 gene in TRAMP mice with $250 \mathrm{ppm}$ in the diet or in TRAMP-C 2 cells when exposed to $5 \mu \mathrm{M}$ genistein $^{(170)}$. The potential of isoflavones to inhibit invasion of breast and prostate tumour cells is furthermore characterised by the downregulation of matrix metalloproteinases (MMP)-2 and 9, as demonstrated in vivo and in vitro with doses $\geq 0.1 \mathrm{mg}$ genistein $/ \mathrm{kg}$ bw in breast cancer mouse xenografts and $\geq 18 \mu \mathrm{M}$ genistein in PC3 and LNCaP cells, respectively ${ }^{(154,172,173)}$. An upregulation of tissue inhibitor of metalloproteinase (TIMP)-1 was only reported for breast cancer with doses $\geq 0.1 \mathrm{mg}$ genistein $/ \mathrm{kg}$ bw in breast cancer mouse xenografts and $74 \mu \mathrm{M}$ in MCF-7 and MDA-MB-231 cells ${ }^{(154)}$. In normal, early cancerous as well as established prostate cancer cells, $10 \mathrm{~nm}$ genistein inhibited the TGF $\beta$ mediated induction of MMP-2 $2^{(172-174)}$. Osteopontin, an extracellular matrix protein secreted by macrophages infiltrating prostate tumours, was reduced at the transcriptional level by genistein $\left(250,500 \mathrm{mg} / \mathrm{kg}\right.$ bw) in TRAMP mice prostate ${ }^{(175)}$.

A physiological impact of isoflavones that has been well documented for breast and prostate cells in vitro and in vivo is the modulation of cell signal transduction through several signalling pathways such as EGF, IGF-1, Akt, NF-кB and MAPK signalling.

The capacity to inhibit mitogen-stimulated growth in breast and prostate cells has been presumed to be due to the inhibition of tyrosine kinase activities associated with critical growth factor receptors ${ }^{(106,176-178)}$. EGFR protein expression was shown to be inhibited in rodent prostate with dietary doses of genistein between 250 and $1000 \mathrm{ppm}^{(179,180)}$. The studies by the group of Lamartiniere showed an age-dependent effect of isoflavones on EGFR protein expression in the mammary gland of Sprague-Dawley rats exposed to $500 \mu \mathrm{g}$ genistein/g bw ${ }^{(181-183)}$. In young 21-day old rats an initial upregulation of EGFR expression in TEBs was observed, followed by a downregulation in adult 50-day old rats. EGFstimulated DNA synthesis was also inhibited by isoflavones in breast and prostate cell lines. In LNCaP and DU-145 prostate cells, genistein and daidzein at $15-60 \mu \mathrm{M}$ showed significant inhibition of EGF-stimulated growth ${ }^{(176)}$, whereas the effect in MCF-7 breast cells is dependent on the genistein concentration added, showing growth inhibition with $0 \cdot 1 \mu \mathrm{M}$ and promotion with $1-10 \mu \mathrm{M}^{(68)}$.

In the prostate of TRAMP mice, a decrease in IGF-1R protein was observed following administration of $250 \mathrm{ppm}$ genistein in the diet ${ }^{(180)}$. In contrast, an in vitro study in MCF-7 breast cancer cells reported an increase in IGF-1R protein expression after exposure to $1 \mu \mathrm{M}$ genistein ${ }^{(184)}$. While IGF1 -stimulated proliferation of rat prostate cancer cells was inhibited by $10 \mu \mathrm{M}$ genistein ${ }^{(177)}$, physiological genistein concentrations $(0 \cdot 1-10 \mu \mathrm{M})$ further increased IGF-1-stimulated growth of MCF-7 cells. Only pharmacological doses of genistein $(>25 \mu \mathrm{M})$ showed an inhibitory effect on breast cancer cell growth ${ }^{(68)}$.

Decreased IGF-1 serum levels were detected in male rats and mice after administration of soy protein and soy isoflavone-enriched diets ${ }^{(147,185)}$. However, contrasted effects of soy or isoflavones on IGF-1 were observed in human studies. Cross-sectional studies in Asian and European women showed no association with soy, isoflavones and soy protein intake and IGF-1 levels ${ }^{(186-188)}$. Experimental studies in women gave controversial results. Consumption of $40 \mathrm{~g}$ soy protein for 3 months led to increased IGF-I plasma levels in postmenopausal women ${ }^{(189)}$. Again, increased plasma IGF-1 and IGFBP-3 concentrations were observed in women consuming $80 \mathrm{mg}$ phytoestrogens (including soy isoflavones) ${ }^{(190)}$ and in premenopausal women after consumption of a low-isoflavone enriched diet $(1 \mathrm{mg} / \mathrm{kg} \mathrm{bw}+\mathrm{d})^{(191)}$. In contrast, a high-isoflavone diet $(2 \mathrm{mg} / \mathrm{kg}$ bw $+\mathrm{d})$ for 3 months resulted in decreased serum IGF-1 concentrations in postmenopausal women ${ }^{(191)}$. 
In men the effect of isoflavone supplementation on serum IGF-1 levels was also inconsistent. A positive correlation was found between intake of soy protein and serum IGF-1 levels in Asian and Caucasian men ${ }^{(192,193)}$ but two intervention studies showed no effect of soy isoflavones ${ }^{(194,195)}$.

Inhibition of the Akt signalling pathway through inhibition of Akt phosphorylation was observed in breast and prostate cell lines exposed to $1-10 \mu \mathrm{M}$ genistein ${ }^{(161,196)}$, as well as in male TRAMP/FVB mice fed with $250-1000$ ppm genistein ${ }^{(197)}$. An abrogation of EGF-stimulated Akt activation was also observed with a high dose $(50 \mu \mathrm{M})$ of genistein ${ }^{(198,199)}$. As PTEN expression is known to be upregulated in prostate and breast cells by low genistein concentrations, as described above, it may mediate the repression of the Akt pathway.

Furthermore it was shown that genistein concentrations above $10 \mu \mathrm{M}$ inhibited the constitutively activated transcription factor NF- $\mathrm{KB}$ in highly invasive MDA-MB-231 breast cells $^{(169)}$. Pharmacological doses of genistein $(>30 \mu \mathrm{M})$ inhibited NF- $\kappa$ B DNA-binding activity and abrogated NF- $\kappa$ B activation induced by DNA damaging agents, EGF and Akt in LNCaP, PC3 prostate and MDA-MB-231 breast cells ${ }^{(198-202)}$. Moreover, protein expression of $\mathrm{IkB}$, the inhibitor of NF-кB in the cytosol, was induced in MCF-7 breast cancer cells by $100 \mu \mathrm{M}$ genistein ${ }^{(165)}$. Conversely, an inhibition of IkB was reported for prostate cells in vitro ${ }^{(201)}$. These effects have been observed using very high isoflavone concentrations. However, Borras et al. recently reported that a dose as low as $0.5 \mu \mathrm{M}$ genistein efficiently activated NF- $\mathrm{KB}$ and subsequently elevated Mn-superoxide dismutase (SOD) expression in MCF-7 cells ${ }^{(203)}$.

Expression of different members of the MAPK cascade is modified by genistein in breast cells. Protein expression of JNK and p38 MAPK was increased when MCF-7 and MCF$10 \mathrm{~F}$ cells were incubated with $0 \cdot 1-45 \mu \mathrm{M}$ genistein $^{(111,158)}$. In contrast, ERK1/2 protein expression was decreased in MCF-10F cells when using a high genistein concentration $(45 \mu \mathrm{M})^{(158)}$ and in the prostate of TRAMP mice fed genistein at $250 \mathrm{ppm}$ in the diet ${ }^{(180)}$. Genistein $(1-10 \mu \mathrm{M})$ also increased ERK1/2 activity in non-tumorigenic epithelial RWPE-1 prostate cells via an estrogenic-dependent mechanism, while supra-physiological concentrations $(>25 \mu \mathrm{M})$ decreased ERK1/2 signalling ${ }^{(114,158,177,204,205)}$. Downstream targets cjun and c-fos, members of the AP-1 complex which is located in promoter regions of several genes discussed in this paragraph, were demonstrated to be upregulated by genistein in breast cancer models in vivo and in vitro. While the dose inducing this effect was $0.1 \mathrm{mg} / \mathrm{kg}$ bw in mice, it was much higher $(74 \mu \mathrm{M})$ in ER positive and negative breast cell lines ${ }^{(154)}$.

Isoflavones such as genistein were also reported to have a possible effect on DNA repair. The tumour suppressor genes BRCA1 and BRCA2 are high penetrance genes associated with an increased risk of estrogen-responsive hereditary cancers such as breast and ovarian cancer and their mutations are also linked to an increased risk of developing androgendependent pathologies such as prostate cancer ${ }^{(206,207)}$. The corresponding proteins are involved in crucial cellular processes like cell proliferation, DNA repair and control of gene expression, notably through the regulation of ER- and AR-dependent transcriptional activities ${ }^{(207,208)}$. Physiological doses of genistein $(0.5-2.5 \mu \mathrm{M})$ upregulated BRCA1 and BRCA2 protein expression in MCF-7 and T47D breast and
$\mathrm{LNCaP}$ and DU-145 prostate cells in vitro ${ }^{(209)}$. An in vivo study reported that administration of $1 \cdot 25-3 \cdot 3 \mu \mathrm{g}$ genistein $/ \mathrm{g}$ bw during prepuberty resulted in a long-lasting increase in BRCA1 mRNA levels in mammary glands of 3 and 8-week old female Sprague-Dawley rats ${ }^{(51)}$. Furthermore, BRCA2 mRNA expression was upregulated in mammary glands of ovariectomised Wistar rats fed an isoflavone-formulated diet (soylife) providing $8 \mu \mathrm{g}$ isoflavones/g bw for 90 days ${ }^{(210)}$. Isoflavones are thus candidate regulators of BRCA1 expression, possibly through their interaction with hormone receptors.

The modulation of antioxidant and xenobiotic enzyme systems towards reduction of oxidative stress and carcinogen detoxification is another key player in cancer prevention. Although the direct antioxidant capacity of soy isoflavones by scavenging free radicals or preventing LDL oxidation was mostly observed at high doses in vitro ${ }^{(211-213)}$, evidence exists that isoflavones may induce antioxidant enzyme systems as shown in vitro in breast and prostate cells at concentrations observed in plasma, or in vivo after soy consumption. Genistein at $10 \mu \mathrm{M}$ induced gene and protein expression of several antioxidant enzymes such as glutathione peroxidase (GPx), glutathione reductase (GSR), microsomal glutathione S-transferase 1 (mGST-1) and metallothionein $1 \mathrm{X}$ (MT-1X) in LAPC-4 prostate cancer cells ${ }^{(214)}$. A lower concentration $(0.5 \mu \mathrm{M})$ of genistein also induced the transcription of $\mathrm{Mn}$ SOD gene in MCF-7 cells ${ }^{(203)}$. Furthermore, isoflavone supplementation of $138 \mathrm{mg} / \mathrm{d}$ for 24 days increased $\mathrm{Cu} / \mathrm{Zn}-\mathrm{SOD}$ activities in erythrocytes of breast cancer survivors ${ }^{(215)}$. Several xenobiotic enzymes involved in the activation of pro-carcinogens or in the detoxication of the carcinogens were influcenced by isoflavones as shown in non-tumorigenic and tumorigenic breast cells using low doses of isoflavones, as well as in rat and human mammary glands. Levels of toxifying Phase I enzymes, such as cytochrome P450 (CYP) 1A1, 1A2 and $1 \mathrm{~B} 1$ were decreased by $430 \mathrm{ppm}$ isoflavones in the diet of female Sprague-Dawley rats ${ }^{(216)}$, by $0 \cdot 7-15 \mu \mathrm{M}$ genistein in MCF-7 cells ${ }^{(217)}$ and in premenopausal women after supplementation with $400 \mathrm{mg}$ daidzein/ $\mathrm{d}^{(218)}$. Detoxifying Phase II enzymes such as GSTP1 and quinone reductase (QR) were upregulated at $1-10 \mu \mathrm{M}$ genistein in non-tumourigenic MCF-10A and tumourigenic MCF-7 and MDA-MB-231 breast cells ${ }^{(219,220)}$

The influence of isoflavones in the metabolism of vitamin D has also been explored. However, the potentially protective effect of genistein through an increase in the synthesis of the antiproliferative metabolite 1,25-dihydroxy-vitamin D3 in breast and prostate cancer cells was only observed at high non-physiological concentrations ${ }^{(221,222)}$. Similarly, inhibition of topoisomerase II and modulation of telomerases were only shown in cell culture models exposed to supra-physiological concentrations of genistein, thus, are unlikely to play a role in the prevention of breast and prostate cancer ${ }^{(196,223,224)}$.

To summarise the mechanisms of action of isoflavones discussed herein for breast cancer it is suggested that the inhibition of cell cycle and induction of apoptosis, promotion of differentiation, as well as the inhibition of angiogenesis, invasion and metastasis are probable modes of action of isoflavones as they were observed at physiologically relevant doses in vivo as well as in vitro. Modulation of the ER pathways and the metabolism of steroid hormones are certainly involved, whereas the regulation of cell signalling pathways 
gave inconsistent results. Some supportive evidence exists for the modulation of EGF, IGF-1, MAPK, Akt and PPAR $\gamma$ pathways, whereas the effects of isoflavones on NF- $\mathrm{B}$ signalling need to be further explored. Furthermore, the stimulation of antioxidant enzyme systems, the modulation of the xenobiotic metabolism towards enhanced detoxification and boosting of DNA repair have also been demonstrated at physiological isoflavone concentrations in breast cells.

The most likely mechanisms of action of isoflavones involved in the prevention of prostate cancer include interaction with AR and ER pathways and improvement of DNA repair. While inhibition of cell cycle was reported to occur only at supra-physiological concentrations, inhibition of angiogenesis, invasion and metastasis may occur at lower doses compatible with dietary exposure. Further studies are needed to establish the effects of isoflavones on the metabolism of steroids, on the modulation of antioxidant enzyme systems and xenobiotic metabolism, as well as on EGF, IGF-1, PPAR $\gamma$ and Akt signalling pathways in prostate cells.

Modulation of vitamin D metabolism, effect on telomerases, direct scavenging of free radicals or inhibition of topoisomerases II were only described at isoflavone concentrations far exceeding the physiological serum levels, raising doubts on their role in the prevention of breast and prostate cancer.

\section{Effects on gene expression and microarray analyses}

Targeted approaches focusing on the activity of one compound on one particular gene or protein, as described in the previous section, have been widely used in pharmacology, generally with success; however, they do not seem to be sufficient to elucidate the mechanisms of action of isoflavones at dietary levels of exposure. Diet is a very complex system, consisting of a huge number of possible combinations of diverse nutrients and micronutrients. Each constituent may have an impact on several metabolic or signalling pathways, and dietary constituents can exert opposite, additional or synergistic effects ${ }^{(225)}$.

Furthermore, there is abundant evidence of cross-talks between ERs and AR, EGF and IGF-1 signalling in breast and prostate cancer cells ${ }^{(226)}$. AR and ERs can be activated by growth factors and compounds that modulate the MAPK cascade $^{(227,228)}$ or the phosphatidylinositol-3 kinase (PI3K)/ Akt-mediated cell survival pathway. In prostate cancers that have evolved to androgen independence, growth factor receptors may activate androgen receptors in the absence of androgens ${ }^{(22)}$. Bidirectional interactions exist. For example, the IGF-1R is directly activated by liganded ER, IGF signalling transcriptionally activates the ER, and IGF-1 and estrogens have synergistic effects on cell cycle signalling cascades and proliferation ${ }^{(230)}$. Signal cross-talk also exists bidirectionally between PPAR $\gamma$ and ER in breast cancer cells ${ }^{(231)}$. ER $\alpha$ and PPAR $\gamma$ pathways have an opposite effect on the regulation of the PI3K/Akt transduction cascade ${ }^{(232)}$. A variety of studies have shown that activated ER and PPAR can inhibit the activity of the transcription factor NF- $\mathrm{B}$, which plays a key role in the control of genes involved in inflammation, cell proliferation and apoptosis ${ }^{(233)}$. A cross-talk between NF- $\kappa \mathrm{B}$ and Akt signalling pathways has been suggested in genistein-treated MDAMB-231 breast cancer cells ${ }^{(199)}$. Moreover, NF- $\kappa$ B activation was reported to inhibit the tumour suppressor PTEN expression, which functions as a negative regulator of the PI3K/Akt pathway ${ }^{(234)}$, whereas activated PPAR $y$ has been shown to upregulate PTEN transcription ${ }^{(161)}$. These non-exhaustive examples of established cross-talks potentially involved in breast and prostate carcinogenesis show how complex the interactions between the various signalling pathways are.

Inter-organ relationships must also be considered. For example, the liver and the immune system certainly play a role in the aetiology of breast and prostate cancer. Therefore it appears evident that targeted approaches are not sufficient to study the effects of dietary compounds on the prevention of these diseases. High-throughput methods such as transcriptomics, proteomics and metabolomics have been recently introduced in the nutrition field.

Large scale gene expression profiling through the use of DNA microarrays consists in measuring simultaneously the expression of hundreds or thousands of genes in a given sample using a single hybridization step. The comparison of these transcriptomic signatures obtained in different experimental conditions offers the possibility to reveal gene networks and signal transduction pathways modulated by a dietary intervention. It allows venturing new hypotheses about mechanisms of action. This is a valuable progress since targeted approaches may favour the systematic focus on a few genes or proteins that are already known to be implicated but may not be the only or the most important actors.

Similarities and differences between phytoestrogen and estrogen activities have been investigated in this way, by comparison of transcriptomic signatures induced by isoflavones or estradiol exposure in MCF-7 cells or mouse estrogen-responsive tissues. Results have been conflicting with some studies describing very similar transcriptional responses ${ }^{(235-237)}$ and others reporting only limited overlapping between expression patterns elicited by estradiol and genistein ${ }^{(238,239)}$. It was suggested that differences in transcriptional signatures may arise from concentration-dependent variations in the magnitude and kinetics of gene expression rather than from modulation of distinct pathways. The question of the dose therefore appears crucial. The number of genes whose expression is affected by estradiol increased with its concentration in MCF-7 cells and in the uterus of immature female rats ${ }^{(240)}$. In human endometrial cancer cells, a strong dose-dependency in the number of genes regulated by genistein was also observed: 2,95 and 508 genes were affected by genistein exposure at $0 \cdot 5,5$ and $50 \mu \mathrm{M}$ respectively ${ }^{(239)}$. Shioda et al. obtained a gene expression profile after exposure of MCF-7 cells to $30 \mathrm{pM}$ estradiol undistinguishable from that obtained with exposure to $3 \mu \mathrm{M}$ genistein, but clearly different to the profile obtained after exposure to $10 \mu \mathrm{M}$ genistein ${ }^{(241)}$. Gene expression profiling thus allows comparing different estrogenic compounds but the results must be interpreted with caution due to this strong dependence on the dose. The few studies that used physiological doses of genistein and estradiol rather showed similar gene expression profiles with genistein and estradiol ${ }^{(242,243)}$ but more studies are clearly needed.

Microarrays may also be useful to study molecular mechanisms. They have been used to identify novel androgen-responsive genes or genes induced in common by peptide growth factors and androgen in human prostate epithelial cells ${ }^{(244)}$. Microarrays have been used to study isoflavone mechanisms of action and build up new hypotheses of research. Only few studies, described below, have applied this technique on cell 
models exposed to physiologically relevant conditions, e.g. with exposures consistent with isoflavone concentrations achievable in humans.

Global gene expression profiles analysed after a 24-h exposure of MCF-7 and T47D cells to $1 \mu \mathrm{M}$ genistein showed large similarities with those obtained after exposure to $30 \mathrm{pm}$ estradiol $^{(242)}$. Using a threshold fold-change of 3 , the authors found 97 upregulated genes, and 36 downregulated genes in genistein-treated MCF-7 cells, mainly involved in cell cycle, apoptosis, DNA metabolism, growth stimulation, cell adhesion, as well as xenobiotic metabolism and transport systems. Fewer genes were regulated by genistein in T47D cells but the same functions were affected. Shioda et al. showed using Affymetrix pangenomic microarrays that exposure of MCF-7 cells to $3 \mu \mathrm{M}$ genistein for $48 \mathrm{~h}$ resulted in the upregulation of genes mainly involved in cell cycle progression, purine and pyrimidine synthesis, as well as steroid biosynthesis ${ }^{(241)}$.

Few studies have been carried out in vivo. Thomsen et al. investigated the effects of neonatal or prepubertal exposure to $270 \mathrm{ppm}$ genistein in the diet at the transcriptional and histological levels by using cDNA microarrays and immunohistochemical analysis of selected regulated genes ${ }^{(243)}$. Changes in gene expression were clearly related to an increase in the number of epithelial mammary cells expressing the genes rather than to a specific regulation within the cells. This finding supported the hypothesis of a role of genistein in promoting earlier differentiation of the mammary gland.

In the mammary gland of male rats life-long exposed to genistein through maternal supplementation then directly in the diet after weaning until postnatal day 90, 90 genes were up or downregulated by at least 2-fold. The following genes were upregulated: growth factors (FGF 5), receptors (IGF-2R, TGF $\beta$ - type 2 receptor, acetylcholine receptor $\beta$, inositol 1,4,5-triphosphate receptor type 1), kinases (adenylate kinase 1 and 3, pyruvate dehydrogenase kinase). Genistein downregulated expression of various enzymes involved in lipid metabolism (phospholipase $C \beta 3$, phospholipase $C \delta 4$, phospholipase $\mathrm{C} \gamma 1$, pancreatic lipase, hepatic lipase), small molecule receptors (glutamate receptor, prostaglandin $\mathrm{F}$ receptor) and solute transporters (solute carrier family 2, 10, 13, 18, voltage-gated sodium channel) as well as organic cationic transporter-like 1 and hydroxysteroid dehydrogenase $11 \beta$ type $1^{(245)}$. The effects on energy metabolism and transport systems constitute new putative mechanisms of action of isoflavones that will have to be investigated further.

In the context of prostate cancer, a series of elegant studies using pangenomic microarrays to investigate the chemopreventive mechanisms of action of isoflavones have been published $^{(246-248)}$. The authors exposed the human androgenresponsive prostate cancer cells $\mathrm{LNCaP}$ to 1,5 and $25 \mu \mathrm{M}$ genistein, daidzein or equol for $48 \mathrm{~h}$, and showed that the number of regulated genes increased markedly with the concentration to which cells were exposed: 521, 484 and 101 genes were regulated by $25 \mu \mathrm{M}$ equol, genistein and daidzein respectively whereas only 14, 3 and 29 genes were regulated by the same compounds at $1 \mu \mathrm{M}$. The nature of the regulated pathways also depended on the concentration: $1 \mu \mathrm{M}$ genistein affected androgen-regulated genes and IGF-1 pathway, concentration of $5 \mu \mathrm{M}$ affected cell cycle control genes and PPAR $\alpha$ signalling, whereas genes related to DNA damage and stress response pathways were upregulated at a $25 \mu \mathrm{M}$ concentration.
Genistein, daidzein and equol induced similar effects on the androgen-responsive genes and IGF-1 pathways, but resulted in a different modulation of steroid/xenobiotic metabolism genes and cell cycle-related genes.

Targeted microarrays may also be useful and are often easier to interpret. Raschke et al. ${ }^{(214)}$ firstly showed with the comet assay that genistein $(1-30 \mu \mathrm{M})$ protected prostate LAPC-4 cells from hydrogen peroxide-induced DNA damage. Using a targeted cDNA macroarray containing 192 genes involved in biotransformation or stress response, the authors showed that genistein modulated the expression of 3 of these genes at $1 \mu \mathrm{M}$ and 19 genes at $10 \mu \mathrm{M}$. Real-time PCR confirmed the induction of three genes encoding products with antioxidant activities, namely GSR, mGST-1 and MT-1X possibly contributing to prevent DNA damage.

Seven other studies reported the use of the microarray technique on prostate cancer cells exposed to very high concentrations of isoflavones $(45-100 \mu \mathrm{M})^{(155,200,249-252)}$. Although these studies may be useful to investigate the putative therapeutic effects of pharmacological doses of isoflavones, they are not useful to examine the mechanisms of action involved in the preventive effects of nutritional doses of isoflavones and thus are beyond the scope of this review. No studies are available to date on gene expression profiles induced by isoflavones in animal prostate.

Although the microarray technology has greatly progressed in the last few years, there are still some limitations. One important issue is the study design and the choice of the appropriate model. Due to high cost of the microarray approach, frequently only one dose or time point is tested, and this does not allow understanding properly the dynamics of changes in gene expression and cell signalling. Another debate is related to the use of cell lines or freshly isolated tissues. Results obtained with cell lines cannot be easily extrapolated to humans due to differences in their genome and to their different environment. On the other hand, isolated tissues are complex and made of a variety of cell types, and reproducibility is hampered by inter-individual differences. However, the heterogeneity of tissue samples and the interactions of the different cell types reflect more precisely the biological gene expression profile. Hence, in order to obtain statistically significant data, a rather large set of samples is required resulting in costly experiments.

Data analysis and interpretation of the large data sets using public databases such as gene network, gene pathway and genome ontology databases are critical issues. The defined cut-off level for differentially expressed genes, based on the fold changes, is also questioned. To date, relatively high fold change thresholds (above 2-fold) have been chosen. However, in microarray analyses using nutritional doses of micronutrients only low fold changes are frequently observed. Low fold changes may actually have a physiological impact, since a small regulation of several genes in one pathway might give an additive effect on the outcome. One must bear in mind that the microarray technology is a precious tool to build up new hypotheses of research while considering the complexity of metabolic and signalling pathways however classical approaches such as quantitative measurement of RNA levels (northern blot, RT-PCR, or in situ hybridization) or protein levels (immunohistochemistry or western blot), as well as biochemical analyses are still necessary for the final validation 
of mechanistic hypotheses and the ultimate establishment of a causal relationship between altered gene expression and a given disease or dietary intervention.

\section{Proteomics}

Rowell et al. used a proteomic approach to investigate the effects of prepubertal exposure to genistein before chemically induced mammary carcinogenesis ${ }^{(253)}$ and found the GTP cyclohydrolase1 protein (GTP-CH1) significantly upregulated in mammary glands. The authors used extensive literature and web searching to find information about related pathways that might explain how this particular protein might play a role in mammary cancer chemoprevention. They speculated that downstream signalling from GTP-CH1 would upregulate tyrosine hydroxylase, resulting in dynamic upregulation of catecholamines. This in turn, would decrease vascular endothelial growth factor receptor 2 (VEGFR2) levels, resulting in decreased ability to promote angiogenesis. Immunoblot and immunohistochemistry analyses confirmed that the proteins of interest (GTP-CH1, tyrosine hydroxylase, and VEGFR2) were modulated in their expression in the lining of mammary epithelial cells of 50-day-old rats. This first study demonstrated the usefulness of proteomics for the discovery of novel pathways that may be involved in cancer prevention by isoflavones.

\section{Metabolomics}

Few metabolomics studies have still been published in the field of nutrition. However, two NMR-based studies have been carried out to investigate the effects of soy isoflavone consumption ${ }^{(254,255)}$. The ${ }^{1} \mathrm{H}$ NMR spectral profiles of plasma and urine from premenopausal women before and following soy or miso consumption revealed significant changes in metabolites associated with energy metabolism. The results suggested an inhibitory effect of isoflavones on glycolysis, resulting in a general shift in energy metabolism from carbohydrate metabolism to lipid metabolism.

Metabolomics is theoretically a better tool to characterize metabolic phenotypes and the effects of dietary interventions on these phenotypes than transcriptomics or proteomics, since changes in gene or protein expression do not necessarily lead to changes in metabolite concentrations. However many technical hurdles still hamper progresses in this approach, as discussed in other reviews ${ }^{(37,256)}$. The present limit of the use of NMR-based metabolomics is the low sensitivity of the technique. The alternative is the use of mass spectrometry-based metabolomics but problems of standardization and robustness still have to be addressed. Furthermore, more efficient methods must still be developed to improve the automated identification of markers.

\section{Epigenetic regulation}

DNA methylation, usually occurring at promoter $\mathrm{CpG}$ islands, as well as acetylation and methylation of critical lysine residues on histones are key epigenetic mechanisms for the silencing of many genes involved in carcinogenesis, including tumour suppressor genes (such as BRCA1, p53, and caveolin-1), genes encoding hormone receptors, DNA repair enzymes, mediators of the apoptosis pathway, and detoxification enzymes ${ }^{(257)}$. Histone modifying enzymes have been shown to directly regulate the expression and activity of ER $\alpha, A R$ and PPAR $\gamma^{(258)}$. Various techniques, such as methylation-specific oligonucleotide microarrays (MSO), methylation target array (MTA), cytosine extension assay and pyrosequencing now allow assessing global and gene specific DNA methylation. For example, using methylationspecific oligonucleotide microarrays, Yu et al., demonstrated that 25 genes among the 105 studied were methylated in prostate cancer cell lines but not in normal primary prostate tissue samples ${ }^{(259)}$. A few available reports indicate that genistein could regulate cancer-related gene transcription by modulating epigenetic events such as DNA methylation and/or histone acetylation, either directly or through an estrogen receptordependent process. Day et al. reported that the consumption of a genistein diet ( $300 \mathrm{ppm})$ by adult male mice was associated to a partial change in the global DNA methylation pattern in the mouse prostate ${ }^{(260)}$. In LNCaP and PC3 cells, genistein reversed DNA hypermethylation and reactivated the methylation-silenced genes retinoic acid receptor $\beta$ (RAR $\beta)$, p16, and $O$-methylguanine methyltransferase (MGMT), but only when used at a high concentration $(20 \mu \mathrm{M})^{(261)}$. However, genistein at $5 \mu \mathrm{M}$ enhanced the activity of the demethylating agent 5-aza-2-deoxycytidine and the histone acetylating drug trichostatin in the reactivation of these genes. Moreover, genistein, equol and to a lesser extent daidzein were shown to stimulate in vitro histone acetylation mediated by ER $\alpha$ or ER $\beta$ and their coactivators, an effect likely to be associated to stimulated transcription ${ }^{(262)}$. Epigenetic effects of isoflavones thus undoubtedly constitute a novel promising axis of research.

In conclusion, although many isoflavone effects have already been established using classical targeted approaches, the exact mechanisms of action have not yet been established. Classical molecular approaches have been used, often in in vitro models, to explore specific hypotheses. The results often still need to be validated in vivo in nutritional conditions. The more recent studies using transcriptomic, proteomic and metabolomic high-throughput techniques obviously demonstrated their potential to describe the complexity of the biological effects of isoflavones and provide us with more comprehensive insights into how isoflavones may contribute to prevent breast and prostate cancers. New hypotheses on the molecular and cellular mechanisms of action of isoflavones have already been opened and there is no doubt that others will rapidly emerge from the increasing use of nutrigenomics approaches in the near future. Major discoveries regarding their mechanisms of action and their variability according to individuals, dose or timing of exposure still seem conceivable.

\section{Acknowledgements}

The publication of this paper was made possible by the financial support of the European Co-operation in the field of Scientific and Technical (COST) Research Action 926 "Impact of new technologies on the health benefits and safety of bioactive plant compounds" (2004-2008). The authors had no conflicts of interest to disclose. 


\section{References}

1. Messina M, Nagata C \& Wu AH (2006) Estimated Asian adult soy protein and isoflavone intakes. Nutr Cancer 55, 1-12.

2. Messina MJ (2003) Emerging evidence on the role of soy in reducing prostate cancer risk. Nutr Rev 61, 117-131.

3. Magee PJ \& Rowland IR (2004) Phyto-oestrogens, their mechanism of action: current evidence for a role in breast and prostate cancer. Br J Nutr 91, 513-531.

4. Wietrzyk J, Gryniciewicz G \& Opolski A (2005) Phytoestrogens in cancer prevention and therapy - mechanisms of their biological activity. Anticancer Res 25, 2357-2366.

5. Hsing AW, Tsao L \& Devesa SS (2000) International trends and patterns of prostate cancer incidence and mortality. Int $J$ Cancer 85, 60-67.

6. Shimizu H, Ross RK, Bernstein L, Yatani R, Henderson BE \& Mack TM (1991) Cancers of the prostate and breast among Japanese and white immigrants in Los Angeles County. $\mathrm{Br} J$ Cancer 63, 963-966.

7. Cook LS, Goldoft M, Schwartz SM \& Weiss NS (1999) Incidence of adenocarcinoma of the prostate in Asian immigrants to the United States and their descendants. J Urol 161, 152-155.

8. Sim HG \& Cheng CWS (2005) Changing demography of prostate cancer in Asia. Eur J Cancer 41, 834-845.

9. Yan L \& Spitznagel EL (2005) Meta-analysis of soy food and risk of prostate cancer in men. Int J Cancer 117, 667-669.

10. Trock BJ, Hilakivi-Clarke L \& Clarke R (2006) Meta-analysis of soy intake and breast cancer risk. J Natl Cancer Inst 98, $459-471$.

11. Shu XO, Jin F, Dai Q, Wen W, Potter JD, Kushi LH, Ruan Z, Gao YT \& Zheng W (2001) Soyfood intake during adolescence and subsequent risk of breast cancer among Chinese women. Cancer Epidemiol Biomarkers Prev 10, 483-488.

12. Wu AH, Wan P, Hankin J, Tseng CC, Yu MC \& Pike MC (2002) Adolescent and adult soy intake and risk of breast cancer in Asian-Americans. Carcinogenesis 23, 1491-1496.

13. Messina M, Kucuk O \& Lampe JW (2006) An overview of the health effects of isoflavones with an emphasis on prostate cancer risk and prostate-specific antigen levels. J AOAC Int 89, $1121-1134$

14. Jarred RA, Keikha M, Dowling C, McPherson SJ, Clare AM, Husband AJ, Pedersen JS, Frydenberg M \& Risbridger GP (2002) Induction of apoptosis in low to moderate-grade human prostate carcinoma by red clover-derived dietary isoflavones. Cancer Epidemiol Biomarkers Prev 11, 1689-1696.

15. Messina M, McCaskill-Stevens W \& Lampe JW (2006) Addressing the soy and breast cancer relationship: review, commentary, and workshop proceedings. $J$ Natl Cancer Inst 98, $1275-1284$

16. Maskarinec GF, Williams AE \& Carlin L (2003) Mammographic densities in a one-year isoflavone intervention. Eur $J$ Cancer Prev 12, 165-169.

17. Maskarinec G, Takata Y, Franke AA, Williams AE \& Murphy SP (2004) A 2-year soy intervention in premenopausal women does not change mammographic densities. J Nutr 134, 3089-3094.

18. Atkinson C, Warren RML, Sala E, Dowsett M, Dunning AM, Healey CS, Runswick S, Day NE \& Bingham SA (2004) Red clover-derived isoflavones and mammographic breast density: a double-blind, randomized, placebo-controlled trial ISRCTN42940165. Breast Cancer Res 6, R170-R179.

19. McMichael-Phillips DF, Harding C, Morton M, Roberts SA, Howell A, Potten CS \& Bundred NJ (1998) Effects of soyprotein supplementation on epithelial proliferation in the histologically normal human breast. Am J Clin Nutr 68, 1431S-1436S.
20. Rosenberg Zand RS, Jenkins DJ \& Diamandis EP (2002) Flavonoids and steroid hormone-dependent cancers. J Chromatogr B Analyt Technol Biomed Life Sci 777, 219-232.

21. Manach C, Williamson G, Morand C, Scalbert A \& Remesy C (2005) Bioavailability and bioefficacy of polyphenols in humans. I. Review of 97 bioavailability studies. Am J Clin Nutr 81, 230S-242S.

22. Miltyk W, Craciunescu CN, Fischer L, Jeffcoat RA, Koch MA, Lopaczynski W, Mahoney C, Crowell J, Paglieri J \& Zeisel SH (2003) Lack of significant genotoxicity of purified soy isoflavones (genistein, daidzein, and glycitein) in 20 patients with prostate cancer. Am J Clin Nutr 77, 875-882.

23. Vergne S, Lamothe V, Chantre P, Potier M, Asselineau J, Perez P, Durand M, Moore N, Bennetau-Pelissero C \& Sauvant P (2007) Influence of ethnicity on bioavailability of isoflavones in human: Caucasian vs Asian. Ann Nutr Metab 51, 208.

24. Heinonen SM, Hoikkala A, Wahala K \& Adlercreutz H (2003) Metabolism of the soy isoflavones daidzein, genistein and glycitein in human subjects. Identification of new metabolites having an intact isoflavonoid skeleton. J Steroid Biochem Mol Biol 87, 285-299.

25. Heinonen SM, Wahala K, Liukkonen KH, Aura AM, Poutanen $\mathrm{K}$ \& Adlercreutz H (2004) Studies of the in vitro intestinal metabolism of isoflavones aid in the identification of their urinary metabolites. J Agric Food Chem 52, 2640-2646.

26. Rufer CE, Glatt H \& Kulling SE (2006) Structural elucidation of hydroxylated metabolites of the isoflavan equol by gas chromatography-mass spectrometry and high-performance liquid chromatography-mass spectrometry. Drug Metab Dispos 34, $51-60$.

27. Setchell KD, Brown NM \& Lydeking-Olsen E (2002) The clinical importance of the metabolite equol - a clue to the effectiveness of soy and its isoflavones. $J$ Nutr 132, $3577-3584$.

28. Atkinson C, Frankenfeld CL \& Lampe JW (2005) Gut bacterial metabolism of the soy isoflavone daidzein: exploring the relevance to human health. Exp Biol Med (Maywood) 230, $155-170$.

29. Song KB, Atkinson C, Frankenfeld CL, Jokela T, Wahala K, Thomas WK \& Lampe JW (2006) Prevalence of daidzeinmetabolizing phenotypes differs between Caucasian and Korean American women and girls. J Nutr 136, 1347-1351.

30. Akaza H, Miyanaga N, Takashima N, Naito S, Hirao Y, Tsukamoto T, Fujioka T, Mori M, Kim WJ, Song JM \& Pantuck AJ (2004) Comparisons of percent equol producers between prostate cancer patients and controls: case-controlled studies of isoflavones in Japanese, Korean and American residents. Jpn J Clin Oncol 34, 86-89.

31. Duncan AM, MerzDemlow BE, Xu X, Phipps WR \& Kurzer MS (2000) Premenopausal equol excretors show plasma hormone profiles associated with lowered risk of breast cancer. Cancer Epidemiol Biomarkers Prev 9, 581-586.

32. Frankenfeld CL, McTiernan A, Tworoger SS, Atkinson C, Thomas WK, Stanczyk FZ, Marcovina SM, Weigle DS, Weiss NS, Holt VL, Schwartz SM \& Lampe JW (2004) Serum steroid hormones, sex hormone-binding globulin concentrations, and urinary hydroxylated estrogen metabolites in post-menopausal women in relation to daidzein-metabolizing phenotypes. J Steroid Biochem Mol Biol 88, 399-408.

33. Nettleton JA, Greany KA, Thomas W, Wangen KE, Adlercreutz H \& Kurzer MS (2005) The effect of soy consumption on the urinary 2:16-hydroxyestrone ratio in postmenopausal women depends on equol production status but is not influenced by probiotic consumption. J Nutr 135, 603-608.

34. Frankenfeld CL, McTiernan A, Aiello EJ, Thomas WK, LaCroix K, Schramm J, Schwartz SM, Holt VL \& Lampe JW (2004) 
Mammographic density in relation to daidzein-metabolizing phenotypes in overweight, postmenopausal women. Cancer Epidemiol Biomarkers Prev 13, 1156-1162.

35. Niculescu MD, Pop EA, Fischer LM \& Zeisel SH (2007) Dietary isoflavones differentially induce gene expression changes in lymphocytes from postmenopausal women who form equol as compared with those who do not. J Nutr Biochem 18, 380-390.

36. Li F, Hullar MAJ \& Lampe JW (2007) Optimization of terminal restriction fragment polymorphism (TRFLP) analysis of human gut microbiota. J Microbiol Methods 68, 303-311.

37. Dettmer K, Aronov PA \& Hammock BD (2007) Mass spectrometry-based metabolomics. Mass Spectrom Rev 26, 51-78.

38. Kaput J \& Rodriguez RL (2004) Nutritional genomics: the next frontier in the postgenomic era. Physiol Genomics 16, 166-177.

39. Hedelin M, Balter KA, Chang ET, Bellocco R, Klint A, Johansson JE, Wiklund F, Thellenberg-Karlsson C, Adami HO \& Gronberg H (2006) Dietary intake of phytoestrogens, estrogen receptor-beta polymorphisms and the risk of prostate cancer. Prostate 66, 1512-1520.

40. Low YL, Taylor JI, Grace PB, Dowsett M, Folkerd E, Doody D, Dunning AM, Scollen S, Mulligan AA, Welch AA, Luben RN, Khaw KT, Day NE, Wareham NJ \& Bingham SA (2005) Polymorphisms in the CYP19 gene may affect the positive correlations between serum and urine phytoestrogen metabolites and plasma androgen concentrations in men. $J$ Nutr $\mathbf{1 3 5}$, $2680-2686$

41. Rhodes DR, Yu JJ, Shanker K, Deshpande N, Varambally R, Ghosh D, Barrette T, Pandey A \& Chinnaiyan AM (2004) Large-scale meta-analysis of cancer microarray data identifies common transcriptional profiles of neoplastic transformation and progression. Proc Natl Acad Sci U S A 101, 9309-9314.

42. Azad NS, Rasool N, Annunziata CM, Minasian L, Whiteley G \& Kohn EC (2006) Proteomics in clinical trials and practice present uses and future promise. Mol Cell Proteomics 5 , $1819-1829$.

43. Adam BL, Qu YS, Davis JW, Ward MD, Clements MA, Cazares LH, Semmes OJ, Schellhammer PF, Yasui Y, Feng ZD \& Wright GL (2002) Serum protein fingerprinting coupled with a pattern-matching algorithm distinguishes prostate cancer from benign prostate hyperplasia and healthy men. Cancer Res 62, 3609-3614.

44. Calvo A, Gonzalez-Moreno O, Yoon CY, Huh JI, Desai K, Nguyen QT \& Green JE (2005) Prostate cancer and the genomic revolution: advances using microarray analyses. Mutat Res 576, 66-79.

45. Jordan KW \& Cheng LL (2007) NMR-based metabolomics approach to target biomarkers for human prostate cancer. Expert Rev Proteomics 4, 389-400.

46. Pollard M \& Suckow MA (2006) Dietary prevention of hormone refractory prostate cancer in Lobund-Wistar rats: a review of studies in a relevant animal model. Comp Med 56, 461-467.

47. Murrill WB, Brown NM, Zhang JX, Manzolillo PA, Barnes S \& Lamartiniere CA (1996) Prepubertal genistein exposure suppresses mammary cancer and enhances gland differentiation in rats. Carcinogenesis 17, 1451-1457.

48. Hilakivi-Clarke L, Cho E \& Clarke R (1998) Maternal genistein exposure mimics the effects of estrogen on mammary gland development in female mouse offspring. Oncol Rep $\mathbf{5}$, 609-616.

49. Hilakivi-Clarke L, Onojafe I, Raygada M, Cho E, Skaar T, Russo I \& Clarke R (1999) Prepubertal exposure to zearalenone or genistein reduces mammary tumorigenesis. $\mathrm{Br} J$ Cancer 80, 1682-1688.

50. Lamartiniere CA (2002) Timing of exposure and mammary cancer risk. J Mammary Gland Biol Neoplasia 7, 67-76.
51. Cabanes A, Wang M, Olivo S, DeAssis S, Gustafsson JA, Khan G \& Hilakivi-Clarke L (2004) Prepubertal estradiol and genistein exposures up-regulate BRCA1 mRNA and reduce mammary tumorigenesis. Carcinogenesis 25, 741-748, Epub 2004 Jan 2016.

52. Hilakivi-Clarke L, Cho E, deAssis S, Olivo S, Ealley E, Bouker KB, Welch JN, Khan G, Clarke R \& Cabanes A (2001) Maternal and prepubertal diet, mammary development and breast cancer risk. $J$ Nutr 131, 154S-157S

53. Hsieh CY, Santell RC, Haslam SZ \& Helferich WG (1998) Estrogenic effects of genistein on the growth of estrogen receptor-positive human breast cancer (MCF-7) cells in vitro and in vivo. Cancer Res 58, 3833-3838.

54. Allred CD, Allred KF, Ju YH, Virant SM \& Helferich WG (2001) Soy diets containing varying amounts of genistein stimulate growth of estrogen-dependent (MCF-7) tumors in a dose-dependent manner. Cancer Res 61, 5045-5050.

55. Ju YH, Allred CD, Allred KF, Karko KL, Doerge DR \& Helferich WG (2001) Physiological concentrations of dietary genistein dose-dependently stimulate growth of estrogendependent human breast cancer (MCF-7) tumors implanted in athymic nude mice. $J$ Nutr 131, 2957-2962.

56. Ju YH, Doerge DR, Allred KF, Allred CD \& Helferich WG (2002) Dietary genistein negates the inhibitory effect of tamoxifen on growth of estrogen-dependent human breast cancer (MCF-7) cells implanted in athymic mice. Cancer Res $\mathbf{6 2}$, 2474-2477.

57. Ju YH, Allred KF, Allred CD \& Helferich WG (2006) Genistein stimulates growth of human breast cancer cells in a novel, postmenopausal animal model, with low plasma estradiol concentrations. Carcinogenesis 27, 1292-1299.

58. Yang JH, Nakagawa H, Tsuta K \& Tsubura A (2000) Influence of perinatal genistein exposure on the development of MNUinduced mammary carcinoma in female Sprague-Dawley rats. Cancer Lett 149, 171-179.

59. Su Y, Eason RR, Geng Y, Till SR, Badger TM \& Simmen RCM (2007) In utero exposure to maternal diets containing soy protein isolate, but not genistein alone, protects young adult rat offspring from NMU-induced mammary tumorigenesis. Carcinogenesis 28, 1046-1051.

60. Padilla-Banks E, Jefferson WN \& Newbold RR (2006) Neonatal exposure to the phytoestrogen genistein alters mammary gland growth and developmental programming of hormone receptor levels. Endocrinology 147, 4871-4882.

61. Dolinoy DC, Weidman JR, Waterland RA \& Jirtle RL (2006) Maternal genistein alters coat color and protects $\mathrm{A}(\mathrm{vy})$ mouse offspring from obesity by modifying the fetal epigenome. Environ Health Perspect 114, 567-572.

62. De Assis S \& Hilakivi-Clarke L (2006) Timing of dietary estrogenic exposures and breast cancer risk. In Estrogens and Human Diseases, pp. 14-35.

63. Jin Z \& MacDonald RS (2002) Soy isoflavones increase latency of spontaneous mammary tumors in mice. $J$ Nutr 132, 3186-3190.

64. Lamartiniere CA, Wang J, Smith-Johnson M \& Eltoum IE (2002) Daidzein: bioavailability, potential for reproductive toxicity, and breast cancer chemoprevention in female rats. Toxicol Sci 65, 228-238.

65. Ju YH, Fultz J, Allred KF, Doerge DR \& Helferich WG (2006) Effects of dietary daidzein and its metabolite, equol, at physiological concentrations on the growth of estrogen-dependent human breast cancer (MCF-7) tumors implanted in ovariectomized athymic mice. Carcinogenesis 27, 856-863.

66. Allred CD, Allred KF, Ju YH, Goeppinger TS, Doerge DR \& Helferich WG (2004) Soy processing influences growth of estrogen-dependent breast cancer tumors. Carcinogenesis $\mathbf{2 5}$ $1649-1657$. 
67. Ohta T, Nakatsugi S, Watanabe K, Kawamori T, Ishikawa F, Morotomi M, Sugie S, Toda T, Sugimura T \& Wakabayashi K (2000) Inhibitory effects of bifidobacterium-fermented soy milk on 2-amino-1-methyl-6-phenylimidazo[4,5-b]pyridineinduced rat mammary carcinogenesis, with a partial contribution of its component isoflavones. Carcinogenesis 21, 937-941.

68. Wang C \& Kurzer MS (1998) Effects of phytoestrogens on DNA synthesis in MCF-7 cells in the presence of estradiol or growth factors. Nutr Cancer 31, 90-100.

69. Le Bail JC, Champavier Y, Chulia AJ \& Habrioux G (2000) Effects of phytoestrogens on aromatase, 3 beta and 17 betahydroxysteroid dehydrogenase activities and human breast cancer cells. Life Sci 66, 1281-1291.

70. Hedlund TE, Maroni PD, Ferucci PG, Dayton R, Barnes S, Jones K, Moore R, Ogden LG, Wahala K, Sackett HM \& Gray KJ (2005) Long-term dietary habits affect soy isoflavone metabolism and accumulation in prostatic fluid in Caucasian men. J Nutr 135, 1400-1406.

71. Hong SJ, Kim SI, Kwon SM, Lee JR \& Chung BC (2002) Comparative study of concentration of isoflavones and lignans in plasma and prostatic tissues of normal control and benign prostatic hyperplasia. Yonsei Med J 43, 236-241.

72. Rannikko A, Petas A, Rannikko S \& Adlercreutz H (2006) Plasma and prostate phytoestrogen concentrations in prostate cancer patients after oral phytoestogen supplementation. Prostate 66, 82-87.

73. Morton MS, Chan PS, Cheng C, Blacklock N, Matos-Ferreira A, Abranches-Monteiro L, Correia R, Lloyd S \& Griffiths K (1997) Lignans and isoflavonoids in plasma and prostatic fluid in men: samples from Portugal, Hong Kong, and the United Kingdom. Prostate 32, 122-128.

74. Guy L, Vedrine N, Urpi-Sarda M, Gil-Izquierdo A, Al-Maharik N, Boiteux JP, Scalbert A, Rémésy C, Botting NP \& Manach C (2007) Orally administered isoflavones are present as glucuronides in the human prostate. Nutr Cancer 60 (In the Press).

75. Maubach J, Depypere HT, Goeman J, Van Der Eycken J, Heyerick A, Bracke ME, Blondeel P \& De Keukeleire D (2004) Distribution of soy-derived phytoestrogens in human breast tissue and biological fluids. Obstet Gynecol 103, 892-898.

76. Dang ZC, Audinot V, Papapoulos SE, Boutin JA \& Lowik CW (2003) Peroxisome proliferator-activated receptor gamma (PPARgamma) as a molecular target for the soy phytoestrogen genistein. J Biol Chem 278, 962-967.

77. Setchell KD, Brown NM, Desai P, Zimmer-Nechemias L, Wolfe BE, Brashear WT, Kirschner AS, Cassidy A \& Heubi JE (2001) Bioavailability of pure isoflavones in healthy humans and analysis of commercial soy isoflavone supplements. J Nutr 131, 1362S-1375S.

78. Busby MG, Jeffcoat AR, Bloedon LT, Koch MA, Black T, Dix KJ, Heizer WD, Thomas BF, Hill JM, Crowell JA \& Zeisel SH (2002) Clinical characteristics and pharmacokinetics of purified soy isoflavones: single-dose administration to healthy men. Am J Clin Nutr 75, 126-136.

79. Zhang Y, Hendrich S \& Murphy PA (2003) Glucuronides are the main isoflavone metabolites in women. J Nutr 133, 399-404.

80. Zhang Y, Song TT, Cunnick JE, Murphy PA \& Hendrich S (1999) Daidzein and genistein glucuronides in vitro are weakly estrogenic and activate human natural killer cells at nutritionally relevant concentrations. J Nutr 129, 399-405.

81. Turner R, Baron T, Wolffram S, Minihane AM, Cassidy A, Rimbach G \& Weinberg PD (2004) Effect of circulating forms of soy isoflavones on the oxidation of low density lipoprotein. Free Radic Res 38, 209-216.

82. Rimbach G, Weinberg PD, de Pascual-Teresa S, Alonso MG, Ewins BA, Turner R, Minihane AM, Botting N, Fairley B, Matsugo S, Uchida Y \& Cassidy A (2004) Sulfation of genistein alters its antioxidant properties and its effect on platelet aggregation and monocyte and endothelial function. Biochim Biophys Acta 1670, 229-237.

83. Pizzagalli F, Varga Z, Huber RD, Folkers G, Meier PJ \& StPierre MV (2003) Identification of steroid sulfate transport processes in the human mammary gland. J Clin Endocrinol Metab 88, 3902-3912.

84. Barnes S (2004) Soy isoflavones-phytoestrogens and what else? J Nutr 134, 1225S-1228S

85. McCarty MF (2006) Isoflavones made simple - genistein's agonist activity for the beta-type estrogen receptor mediates their health benefits. Med Hypotheses 66, 1093-1114.

86. Sarkar FH \& Li YW (2004) Cell signaling pathways altered by natural chemopreventive agents. Mutat Res 555, 53-64.

87. Pettersson K \& Gustafsson JA (2001) Role of estrogen receptor beta in estrogen action. Annu Rev Physiol 63, 165-192.

88. Lindberg MK, Moverare S, Skrtic S, Gao H, Dahlman-Wright K, Gustafsson JA \& Ohlsson C (2003) Estrogen receptor (ER)beta reduces ER alpha-regulated gene transcription, supporting a 'Ying Yang' relationship between ER alpha and ER beta in mice. Mol Endocrinol 17, 203-208.

89. Liu MM, Albanese C, Anderson CM, Hilty K, Webb P, Uht RM, Price RH, Pestell RG \& Kushner PJ (2002) Opposing action of estrogen receptors alpha and beta on cyclin D1 gene expression. J Biol Chem 277, 24353-24360.

90. Leygue E, Dotzlaw H, Watson PH \& Murphy LC (1998) Altered estrogen receptor alpha and beta messenger RNA expression during human breast tumorigenesis. Cancer Res 58, 3197-3201.

91. Maggiolini M, Bonofiglio D, Marsico S, Panno ML, Cenni B, Picard D \& Ando S (2001) Estrogen receptor alpha mediates the proliferative but not the cytotoxic dose-dependent effects of two major phytoestrogens on human breast cancer cells. Mol Pharmacol 60, 595-602.

92. Power KA \& Thompson LU (2003) Ligand-induced regulation of ERalpha and ERbeta is indicative of human breast cancer cell proliferation. Breast Cancer Res Treat 81, 209-221.

93. Cappelletti V, Miodini P, Di Fronzo G \& Daidone MG (2006) Modulation of estrogen receptor-beta isoforms by phytoestrogens in breast cancer cells. Int J Oncol 28, 1185-1191.

94. Gallo D, Giacomelli S, Cantelmo F, Zannoni GF, Ferrandina G, Fruscella E, Riva A, Morazzoni P, Bombardelli E, Mancuso S \& Scambia G (2001) Chemoprevention of DMBA-induced mammary cancer in rats by dietary soy. Breast Cancer Res Treat 69, 153-164.

95. Dalu A, Blaydes BS, Bryant CW, Latendresse JR, Weis CC \& Barry Delclos K (2002) Estrogen receptor expression in the prostate of rats treated with dietary genistein. J Chromatogr B Analyt Technol Biomed Life Sci 777, 249-260.

96. Fritz WA, Wang J, Eltoum IE \& Lamartiniere CA (2002) Dietary genistein down-regulates androgen and estrogen receptor expression in the rat prostate. Mol Cell Endocrinol 186, 89-99.

97. Wang J, Eltoum IE \& Lamartiniere CA (2007) Genistein chemoprevention of prostate cancer in TRAMP mice. J Carcinog 6, 3 .

98. Kuiper G, Carlsson B, Grandien K, Enmark E, Haggblad J, Nilsson S \& Gustafsson JA (1997) Comparison of the ligand binding specificity and transcript tissue distribution of estrogen receptors alpha and beta. Endocrinology 138, 863-870.

99. Kuiper GG, Lemmen JG, Carlsson B, Corton JC, Safe SH, van der Saag PT, van der Burg B \& Gustafsson JA (1998) Interaction of estrogenic chemicals and phytoestrogens with estrogen receptor beta. Endocrinology 139, 4252-4263.

100. Matthews J \& Gustafsson JA (2003) Estrogen signaling: a subtle balance between ERalpha and ERbeta. Mol Interv 3, 281-292.

101. Pike ACW, Brzozowski AM \& Hubbard RE (2000) A structural biologist's view of the oestrogen receptor. J Steroid Biochem Mol Biol 74, 261-268. 
102. Morito K, Hirose T, Kinjo J, Hirakawa T, Okawa M, Nohara T, Ogawa S, Inoue S, Muramatsu M \& Masamune Y (2001) Interaction of phytoestrogens with estrogen receptors alpha and beta. Biol Pharm Bull 24, 351-356.

103. Kostelac D, Rechkemmer G \& Briviba K (2003) Phytoestrogens modulate binding response of estrogen receptors alpha and beta to the estrogen response element. J Agric Food Chem 51, 7632-7635.

104. Limer JL \& Speirs V (2004) Phyto-oestrogens and breast cancer chemoprevention. Breast Cancer Res 6, 119-127.

105. Maggiolini M, Vivacqua A, Carpino A, Bonofiglio D, Fasanella G, Salerno M, Picard D \& Ando S (2002) The mutant androgen receptor T877A mediates the proliferative but not the cytotoxic dose-dependent effects of genistein and quercetin on human LNCaP prostate cancer cells. Mol Pharmacol 62, $1027-1035$.

106. Fioravanti L, Cappelletti V, Miodini P, Ronchi E, Brivio M \& Di Fronzo G (1998) Genistein in the control of breast cancer cell growth: insights into the mechanism of action in vitro. Cancer Lett 130, 143-152.

107. Wood CE, Register TC, Franke AA, Anthony MS \& Cline JM (2006) Dietary soy isoflavones inhibit estrogen effects in the postmenopausal breast. Cancer Res 66, 1241-1249.

108. Wang TT, Sathyamoorthy N \& Phang JM (1996) Molecular effects of genistein on estrogen receptor mediated pathways. Carcinogenesis 17, 271-275.

109. Sathyamoorthy N \& Wang TT (1997) Differential effects of dietary phyto-oestrogens daidzein and equol on human breast cancer MCF-7 cells. Eur J Cancer 33, 2384-2389.

110. Hargreaves DF, Potten CS, Harding C, Shaw LE, Morton MS, Roberts SA, Howell A \& Bundred NJ (1999) Two-week dietary soy supplementation has an estrogenic effect on normal premenopausal breast. J Clin Endocrinol Metab 84, 4017-4024.

111. Leung LK \& Wang TT (2000) Bcl-2 is not reduced in the death of MCF-7 cells at low genistein concentration. $J$ Nutr 130, 2922-2926.

112. Po LS, Wang TT, Chen ZY \& Leung LK (2002) Genisteininduced apoptosis in MCF-7 cells involves changes in Bak and Bcl-x without evidence of anti-oestrogenic effects. $\mathrm{Br} J$ Nutr 88, 463-469.

113. Bektic J, Berger AP, Pfeil K, Dobler G, Bartsch G \& Klocker $\mathrm{H}$ (2004) Androgen receptor regulation by physiological concentrations of the isoflavonoid genistein in androgen-dependent LNCaP cells is mediated by estrogen receptor beta. Eur Urol 45, 245-251, discussion 251.

114. Gao S, Liu GZ \& Wang ZX (2004) Modulation of androgen receptor-dependent transcription by resveratrol and genistein in prostate cancer cells. Prostate 59, 214-225.

115. Davis JN, Muqim N, Bhuiyan M, Kucuk O, Pienta KJ \& Sarkar FH (2000) Inhibition of prostate specific antigen expression by genistein in prostate cancer cells. Int J Oncol 16, $1091-1097$.

116. Davis JN, Kucuk O \& Sarkar FH (2002) Expression of prostate-specific antigen is transcriptionally regulated by genistein in prostate cancer cells. Mol Carcinog 34, 91-101.

117. Hamilton-Reeves JM, Rebello SA, Thomas W, Slaton JW \& Kurzer MS (2007) Isoflavone-rich soy protein isolate suppresses androgen receptor expression without altering estrogen receptor-beta expression or serum hormonal profiles in men at high risk of prostate cancer. J Nutr 137, 1769-1775.

118. Weber KS, Setchell KDR, Stocco DM \& Lephart ED (2001) Dietary soy-phytoestrogens decrease testosterone levels and prostate weight without altering $\mathrm{LH}$, prostate 5 alpha-reductase or testicular steroidogenic acute regulatory peptide levels in adult male Sprague-Dawley rats. J Endocrinol 170, 591-599.

119. Zhou JR, Yu LY, Zhong Y, Nassr RL, Franke AA, Gaston SM \& Blackburn GL (2002) Inhibition of orthotopic growth and metastasis of androgen-sensitive human prostate tumors in mice by bioactive soybean components. Prostate 53, 143-153.

120. Lund TD, Munson DJ, Haldy ME, Setchell KDR, Lephart ED \& Handa RJ (2004) Equol is a novel anti-androgen that inhibits prostate growth and hormone feedback. Biol Reprod 70, $1188-1195$.

121. Sun XY, Plouzek CA, Henry JP, Wang TTY \& Phang JM (1998) Increased UDP-glucuronosyltransferase activity and decreased prostate specific antigen production by biochanin A in prostate cancer cells. Cancer Res 58, 2379-2384.

122. Makela S, Poutanen M, Lehtimaki J, Kostian ML, Santti R \& Vihko R (1995) Estrogen-specific 17-beta-hydroxysteroid oxidoreductase type-1 (Ec-1.1.1.62) as a possible target for the action of phytoestrogens. Proc Soc Exp Biol Med 208, $51-59$.

123. Whitehead SA \& Rice S (2006) Endocrine-disrupting chemicals as modulators of sex steroid synthesis. Best Pract Res Clin Endocrinol Metab 20, 45-61.

124. Kao YC, Zhou C, Sherman M, Laughton CA \& Chen S (1998) Molecular basis of the inhibition of human aromatase (estrogen synthetase) by flavone and isoflavone phytoestrogens: a sitedirected mutagenesis study. Environ Health Perspect 106, $85-92$.

125. Makela S, Poutanen M, Kostian ML, Lehtimaki N, Strauss L, Santti R \& Vihko R (1998) Inhibition of 17beta-hydroxysteroid oxidoreductase by flavonoids in breast and prostate cancer cells. Proc Soc Exp Biol Med 217, 310-316.

126. Evans BA, Griffiths K \& Morton MS (1995) Inhibition of 5 alpha-reductase in genital skin fibroblasts and prostate tissue by dietary lignans and isoflavonoids. $J$ Endocrinol 147, 295-302.

127. Kirk CJ, Harris RM, Wood DM, Waring RH \& Hughes PJ (2001) Do dietary phytoestrogens influence susceptibility to hormone-dependent cancer by disrupting the metabolism of endogenous oestrogens? Biochem Soc Trans 29, 209-216.

128. Wong CK \& Keung WM (1997) Daidzein sulfoconjugates are potent inhibitors of sterol sulfatase (EC 3.1.6.2). Biochem Biophys Res Commun 233, 579-583.

129. Harris RM, Wood DM, Bottomley L, Blagg S, Owen K, Hughes PJ, Waring RH \& Kirk CJ (2004) Phytoestrogens are potent inhibitors of estrogen sulfation: implications for breast cancer risk and treatment. J Clin Endocrinol Metab 89, 1779-1787.

130. Kumar NB, Cantor A, Allen K, Riccardi D \& Cox CE (2002) The specific role of isoflavones on estrogen metabolism in premenopausal women. Cancer 94, 1166-1174.

131. Kurzer MS (2002) Hormonal effects of soy in premenopausal women and men. $J$ Nutr 132, 570S-573S.

132. Cassidy A, Bingham S \& Setchell KDR (1994) Biological effects of a diet of soy protein-rich in isoflavones on the menstrual-cycle of premenopausal women. Am J Clin Nutr 60, 333-340.

133. Mousavi Y \& Adlercreutz H (1993) Genistein is an effective stimulator of sex-hormone binding globulin production in hepatocarcinoma human liver-cancer cells and suppresses proliferation of these cells in culture. Steroids 58, 301-304.

134. Wood CE, Register TC \& Cline JM (2007) Soy isoflavonoid effects on endogenous estrogen metabolism in postmenopausal female monkeys. Carcinogenesis 28, 801-808.

135. Duncan AM, Underhill KE, Xu X, Lavalleur J, Phipps WR \& Kurzer MS (1999) Modest hormonal effects of soy isoflavones in postmenopausal women. J Clin Endocrinol Metab 84, 3479-3484.

136. Maskarinec G, Williams AE, Inouye JS, Stanczyk FZ \& Franke AA (2002) A randomized isoflavone intervention among premenopausal women. Cancer Epidemiol Biomarkers Prev 11, 195-201. 
137. Duncan AM, Merz BE, Xu X, Nagel TC, Phipps WR \& Kurzer MS (1999) Soy isoflavones exert modest hormonal effects in premenopausal women. J Clin Endocrinol Metab 84, 192-197.

138. Mezei O, Banz WJ, Steger RW, Peluso MR, Winters TA \& Shay N (2003) Soy isoflavones exert antidiabetic and hypolipidemic effects through the PPAR pathways in obese Zucker rats and murine RAW 264.7 cells. J Nutr 133, 1238-1243.

139. Chacko BK, Chandler RT, D’Alessandro TL, Mundhekar A, Khoo NKH, Botting N, Barnes S \& Patel RP (2007) Anti-inflammatory effects of isoflavones are dependent on flow and human endothelial cell PPAR gamma. J Nutr 137, 351-356.

140. Horia E \& Watkins BA (2007) Complementary actions of docosahexaenoic acid and genistein on $\operatorname{COX}-2, \operatorname{PGE}(2)$ and invasiveness in MDA-MB-231 breast cancer cells. Carcinogenesis 28, 809-815.

141. Elstner E, Muller C, Koshizuka K, Williamson EA, Park D, Asou H, Shintaku P, Said JW, Heber D \& Koeffler HP (1998) Ligands for peroxisome proliferator-activated receptor gamma and retinoic acid receptor inhibit growth and induce apoptosis of human breast cancer cells in vitro and in BNX mice. Proc Natl Acad Sci U S A 95, 8806-8811.

142. Mueller E, Sarraf P, Tontonoz P, Evans RM, Martin KJ, Zhang M, Fletcher C, Singer S \& Spiegelman BM (1998) Terminal differentiation of human breast cancer through PPAR gamma. Mol Cell 1, 465-470.

143. Mueller E, Smith M, Sarraf P, Kroll T, Aiyer A, Kaufman DS, Oh W, Demetri G, Figg WD, Zhou XP, Eng C, Spiegelman BM \& Kantoff PW (2000) Effects of ligand activation of peroxisome proliferator-activated receptor gamma in human prostate cancer. Proc Natl Acad Sci U S A 97, 10990-10995.

144. Theocharis S, Margeli A, Vielh P \& Kouraklis G (2004) Peroxisome proliferator-activated receptor-gamma ligands as cell-cycle modulators. Cancer Treat Rev 30, 545-554.

145. Suzuki T, Hayashi S, Miki Y, Nakamura Y, Moriya T, Sugawara A, Ishida T, Ohuchi N \& Sasano H (2006) Peroxisome proliferator-activated receptor gamma in human breast carcinoma: a modulator of estrogenic actions. Endocr Relat Cancer 13, 233-250.

146. Han S \& Roman J (2007) Peroxisome proliferator-activated receptor gamma: a novel target for cancer therapeutics? Anticancer Drugs 18, 237-244.

147. Zhou JR, Gugger ET, Tanaka T, Guo Y, Blackburn GL \& Clinton SK (1999) Soybean phytochemicals inhibit the growth of transplantable human prostate carcinoma and tumor angiogenesis in mice. $J$ Nutr 129, 1628-1635.

148. Shen JC, Klein RD, Wei Q, Guan Y, Contois JH, Wang TT, Chang S \& Hursting SD (2000) Low-dose genistein induces cyclin-dependent kinase inhibitors and $\mathrm{G}(1)$ cell-cycle arrest in human prostate cancer cells. Mol Carcinog 29, 92-102.

149. Davis JN, Singh B, Bhuiyan M \& Sarkar FH (1998) Genisteininduced upregulation of p21(WAF1), downregulation of cyclin $\mathrm{B}$, and induction of apoptosis in prostate cancer cells. Nutr Cancer 32, 123-131.

150. Hewitt AL \& Singletary KW (2003) Soy extract inhibits mammary adenocarcinoma growth in a syngeneic mouse model. Cancer Lett 192, 133-143.

151. Pagliacci MC, Smacchia M, Migliorati G, Grignani F, Riccardi C \& Nicoletti I (1994) Growth-inhibitory effects of the natural phyto-oestrogen genistein in MCF-7 human breast cancer cells. Eur J Cancer 30A, 1675-1682.

152. Frey RS, Li J \& Singletary KW (2001) Effects of genistein on cell proliferation and cell cycle arrest in nonneoplastic human mammary epithelial cells: involvement of Cdc2, p21(waf/ cip1), p27(kip1), and Cdc25C expression. Biochem Pharmacol 61, 979-989.

153. King RW, Jackson PK \& Kirschner MW (1994) Mitosis in transition. Cell 79, 563-571.
154. Shao ZM, Wu J, Shen ZZ \& Barsky SH (1998) Genistein exerts multiple suppressive effects on human breast carcinoma cells. Cancer Res 58, 4851-4857.

155. Rice L, Samedi VG, Medrano TA, Sweeney CA, Baker HV, Stenstrom A, Furman J \& Shiverick KT (2002) Mechanisms of the growth inhibitory effects of the isoflavonoid biochanin A on LNCaP cells and xenografts. Prostate 52, 201-212.

156. Touny LH \& Banerjee PP (2006) Identification of both Myt-1 and Wee- 1 as necessary mediators of the p21-independent inactivation of the cdc-2/cyclin B1 complex and growth inhibition of TRAMP cancer cells by genistein. Prostate 66, $1542-1555$.

157. Liao CH, Pan SL, Guh JH \& Teng CM (2004) Genistein inversely affects tubulin-binding agent-induced apoptosis in human breast cancer cells. Biochem Pharmacol 67, 2031-2038.

158. Frey RS \& Singletary KW (2003) Genistein activates p38 mitogen-activated protein kinase, inactivates ERK1/ERK2 and decreases $\mathrm{Cdc} 25 \mathrm{C}$ expression in immortalized human mammary epithelial cells. J Nutr 133, 226-231.

159. Gautier J, Solomon MJ, Booher RN, Bazan JF \& Kirschner MW (1991) cdc25 is a specific tyrosine phosphatase that directly activates p34cdc2. Cell 67, 197-211.

160. Li Y, Upadhyay S, Bhuiyan M \& Sarkar FH (1999) Induction of apoptosis in breast cancer cells MDA-MB-231 by genistein. Oncogene 18, 3166-3172.

161. Waite KA, Sinden MR \& Eng C (2005) Phytoestrogen exposure elevates PTEN levels. Hum Mol Genet 14, $1457-1463$.

162. Eto I (2006) Nutritional and chemopreventive anti-cancer agents up-regulate expression of p27Kip1, a cyclin-dependent kinase inhibitor, in mouse JB6 epidermal and human MCF7, MDA-MB-321 and AU565 breast cancer cells. Cancer Cell Int 6, 20.

163. Dave B, Eason RR, Till SR, Geng Y, Velarde MC, Badger TM \& Simmen RC (2005) The soy isoflavone genistein promotes apoptosis in mammary epithelial cells by inducing the tumor suppressor PTEN. Carcinogenesis 26, 1793-1803.

164. Kobayashi T, Nakata T \& Kuzumaki T (2002) Effect of flavonoids on cell cycle progression in prostate cancer cells. Cancer Lett 176, 17-23.

165. Kazi A, Daniel KG, Smith DM, Kumar NB \& Dou QP (2003) Inhibition of the proteasome activity, a novel mechanism associated with the tumor cell apoptosis-inducing ability of genistein. Biochem Pharmacol 66, 965-976.

166. Li X, Marani M, Mannucci R, Kinsey B, Andriani F, Nicoletti I, Denner L \& Marcelli M (2001) Overexpression of BCL$\mathrm{X}(\mathrm{L})$ underlies the molecular basis for resistance to staurosporine-induced apoptosis in PC-3 cells. Cancer Res 61, 1699-1706.

167. Bemis DL, Capodice JL, Desai M, Buttyan R \& Katz AE (2004) A concentrated aglycone isoflavone preparation (GCP) that demonstrates potent anti-prostate cancer activity in vitro and in vivo. Clin Cancer Res 10, 5282-5292.

168. Cao F, Jin TY \& Zhou YF (2006) Inhibitory effect of isoflavones on prostate cancer cells and PTEN gene. Biomed Environ Sci 19, 35-41.

169. Valachovicova T, Slivova V, Bergman H, Shuherk J \& Sliva D (2004) Soy isoflavones suppress invasiveness of breast cancer cells by the inhibition of NF-kappa B/AP-1-dependent and independent pathways. Int J Oncol 25, 1389-1395.

170. El Touny LH \& Banerjee PP (2007) Genistein induces the metastasis suppressor kangai-1 which mediates its anti-invasive effects in TRAMP cancer cells. Biochem Biophys Res Commun 361, 169-175.

171. Skogseth H, Larsson E \& Halgunset J (2006) The invasive behaviour of prostatic cancer cells is suppressed by inhibitors of tyrosine kinase. Apmis 114, 61-66. 
172. Kumi-Diaka JK, Hassanhi M, Merchant K \& Horman V (2006) Influence of genistein isoflavone on matrix metalloproteinase-2 expression in prostate cancer cells. J Med Food 9, 491-497.

173. Xu L \& Bergan RC (2006) Genistein inhibits matrix metalloproteinase type 2 activation and prostate cancer cell invasion by blocking the transforming growth factor beta-mediated activation of mitogen-activated protein kinase-activated protein kinase 2-27-kDa heat shock protein pathway. Mol Pharmacol 70, 869-877.

174. Huang XK, Chen S, Xu L, Liu YQ, Deb DK, Platanias LC \& Bergan RC (2005) Genistein inhibits p38 map kinase activation, matrix metalloproteinase type 2 , and cell invasion in human prostate epithelial cells. Cancer Res 65, 3470-3478.

175. Mentor-Marcel R, Lamartiniere CA, Eltoum IA, Greenberg NM \& Elgavish A (2005) Dietary genistein improves survival and reduces expression of osteopontin in the prostate of transgenic mice with prostatic adenocarcinoma (TRAMP). J Nutr 135, 989-995.

176. Peterson G \& Barnes S (1993) Genistein and biochanin A inhibit the growth of human prostate cancer cells but not epidermal growth factor receptor tyrosine autophosphorylation. Prostate 22, 335-345.

177. Wang S, DeGroff VL \& Clinton SK (2003) Tomato and soy polyphenols reduce insulin-like growth factor-I-stimulated rat prostate cancer cell proliferation and apoptotic resistance in vitro via inhibition of intracellular signaling pathways involving tyrosine kinase. J Nutr 133, 2367-2376.

178. Akiyama T, Ishida J, Nakagawa S, Ogawara H, Watanabe S, Itoh N, Shibuya M \& Fukami Y (1987) Genistein, a specific inhibitor of tyrosine-specific protein kinases. $\mathrm{J}$ Biol Chem 262, 5592-5595.

179. Dalu A, Haskell JF, Coward L \& Lamartiniere CA (1998) Genistein, a component of soy, inhibits the expression of the EGF and ErbB2/Neu receptors in the rat dorsolateral prostate. Prostate 37, 36-43.

180. Wang J, Eltoum IE \& Lamartiniere CA (2004) Genistein alters growth factor signaling in transgenic prostate model (TRAMP). Mol Cell Endocrinol 219, 171-180.

181. Brown NM, Wang J, Cotroneo MS, Zhao YX \& Lamartiniere CA (1998) Prepubertal genistein treatment modulates TGFalpha, EGF and EGF-receptor mRNAs and proteins in the rat mammary gland. Mol Cell Endocrinol 144, 149-165.

182. Lamartiniere CA, Cotroneo MS, Fritz WA, Wang J, MentorMarcel R \& Elgavish A (2002) Genistein chemoprevention: timing and mechanisms of action in murine mammary and prostate. J Nutr 132, 552S-558S.

183. Cotroneo MS, Wang J, Fritz WA, Eltoum IE \& Lamartiniere CA (2002) Genistein action in the prepubertal mammary gland in a chemoprevention model. Carcinogenesis 23, 1467-1474.

184. Chen WF \& Wong MS (2004) Genistein enhances insulin-like growth factor signaling pathway in human breast cancer (MCF-7) cells. J Clin Endocrinol Metab 89, 2351-2359.

185. Aukema HM \& Housini I (2001) Dietary soy protein effects on disease and IGF-I in male and female Han:SPRD-cy rats. Kidney Int 59, 52-61.

186. Nagata C, Shimizu H, Takami R, Hayashi M, Takeda N \& Yasuda K (2003) Dietary soy and fats in relation to serum insulin-like growth factor-1 and insulin-like growth factorbinding protein-3 levels in premenopausal Japanese women. Nutr Cancer 45, 185-189.

187. Allen NE, Appleby PN, Davey GK, Kaaks R, Rinaldi S \& Key TJ (2002) The associations of diet with serum insulin-like growth factor I and its main binding proteins in 292 women meat-eaters, vegetarians, and vegans. Cancer Epidemiol Biomarkers Prev 11, 1441-1448.

188. Vrieling A, Voskuil DW, Bueno de Mesquita HB, Kaaks R, van Noord PA, Keinan-Boker L, van Gils CH \& Peeters PH
(2004) Dietary determinants of circulating insulin-like growth factor (IGF)-I and IGF binding proteins 1, -2 and -3 in women in The Netherlands. Cancer Causes Control 15, $787-796$.

189. Arjmandi BH, Khalil DA, Smith BJ, Lucas EA, Juma S, Payton ME \& Wild RA (2003) Soy protein has a greater effect on bone in postmenopausal women not on hormone replacement therapy, as evidenced by reducing bone resorption and urinary calcium excretion. J Clin Endocrinol Metab 88, $1048-1054$.

190. Woodside JV, Campbell MJ, Denholm EE, Newton L, Honour JW, Morton MS, Young IS \& Leathem AJ (2006) Short-term phytoestrogen supplementation alters insulin-like growth factor profile but not lipid or antioxidant status. J Nutr Biochem 17, 211-215.

191. Wangen KE, Duncan AM, Merz-Demlow BE, Xu X, Marcus R, Phipps WR \& Kurzer MS (2000) Effects of soy isoflavones on markers of bone turnover in premenopausal and postmenopausal women. J Clin Endocrinol Metab 85, 3043-3048.

192. Probst-Hensch NM, Wang H, Goh VH, Seow A, Lee HP \& Yu MC (2003) Determinants of circulating insulin-like growth factor I and insulin-like growth factor binding protein 3 concentrations in a cohort of Singapore men and women. Cancer Epidemiol Biomarkers Prev 12, 739-746.

193. Khalil DA, Lucas EA, Juma S, Smith BJ, Payton ME \& Arjmandi BH (2002) Soy protein supplementation increases serum insulinlike growth factor-I in young and old men but does not affect markers of bone metabolism. J Nutr 132, 2605-2608.

194. Adams KF, Newton KM, Chen C, Emerson SS, Potter JD, White E \& Lampe JW (2003) Soy Isoflavones do not modulate circulating insulin-like growth factor concentrations in an older population in an intervention trial. J Nutr 133, 1316-1319.

195. Hussain M, Banerjee M, Sarkar FH, Djuric Z, Pollak MN, Doerge D, Fontana J, Chinni S, Davis J, Forman J, Wood DP \& Kucuk O (2003) Soy isoflavones in the treatment of prostate cancer. Nutr Cancer 47, 111-117.

196. Jagadeesh S, Kyo S \& Banerjee PP (2006) Genistein represses telomerase activity via both transcriptional and posttranslational mechanisms in human prostate cancer cells. Cancer Res 66, 2107-2115.

197. El Touny LH \& Banerjee PP (2007) Akt/GSK3 pathway as a target in genistein-induced inhibition of TRAMP prostate cancer progression towards a poorly differentiated phenotype. Carcinogenesis.

198. Li Y \& Sarkar FH (2002) Down-regulation of invasion and angiogenesis-related genes identified by cDNA microarray analysis of PC3 prostate cancer cells treated with genistein. Cancer Lett 186, 157-164.

199. Gong L, Li Y, Nedeljkovic-Kurepa A \& Sarkar FH (2003) Inactivation of NF-kappaB by genistein is mediated via Akt signaling pathway in breast cancer cells. Oncogene 22, 4702-4709.

200. Li Y \& Sarkar FH (2002) Gene expression profiles of genistein-treated PC3 prostate cancer cells. J Nutr 132, 3623-3631.

201. Davis JN, Kucuk O \& Sarkar FH (1999) Genistein inhibits NFkappa B activation in prostate cancer cells. Nutr Cancer 35, $167-174$.

202. Vanden Berghe W, Dijsselbloem N, Vermeulen L, Ndlovu N, Boone E \& Haegeman G (2006) Attenuation of mitogen- and stress-activated protein kinase-1-driven nuclear factor-kappaB gene expression by soy isoflavones does not require estrogenic activity. Cancer Res 66, 4852-4862.

203. Borras C, Gambini J, Gomez-Cabrera MC, Sastre J, Pallardo FV, Mann GE \& Vina J (2006) Genistein, a soy isoflavone, up-regulates expression of antioxidant genes: involvement of estrogen receptors, ERK1/2, and NF kappa B. FASEB J 20, 2136.

204. Wang XY, Clubbs EA \& Bomser JA (2006) Genistein modulates prostate epithelial cell proliferation via estrogen- and 
extracellular signal-regulated kinase-dependent pathways. $J$ Nutr Biochem 17, 204-210.

205. Clubbs EA \& Bomser JA (2007) Glycitein activates extracellular signal-regulated kinase via vascular endothelial growth factor receptor signaling in nontumorigenic (RWPE-1) prostate epithelial cells. J Nutr Biochem 18, 525-532.

206. Thompson D \& Easton DF (2002) Cancer incidence in BRCA1 mutation carriers. J Natl Cancer Inst 94, 1358-1365.

207. Boulton SJ (2006) Cellular functions of the BRCA tumoursuppressor proteins. Biochem Soc Trans 34, 633-645.

208. Rosen EM, Fan S, Pestell RG \& Goldberg ID (2003) BRCA1 in hormone-responsive cancers. Trends Endocrinol Metab 14, 378-385.

209. Fan S, Meng Q, Auborn K, Carter T \& Rosen EM (2006) BRCA1 and BRCA2 as molecular targets for phytochemicals indole-3-carbinol and genistein in breast and prostate cancer cells. Br J Cancer 94, 407-426.

210. Vissac-Sabatier C, Coxam V, Dechelotte P, Picherit C, Horcajada MN, Davicco MJ, Lebecque P, Bignon YJ \& BernardGallon D (2003) Phytoestrogen-rich diets modulate expression of Brca1 and Brca2 tumor suppressor genes in mammary glands of female Wistar rats. Cancer Res 63, 6607-6612.

211. Rufer CE \& Kulling SE (2006) Antioxidant activity of isoflavones and their major metabolites using different in vitro assays. J Agric Food Chem 54, 2926-2931.

212. Wei H, Wei L, Frenkel K, Bowen R \& Barnes S (1993) Inhibition of tumor promoter-induced hydrogen peroxide formation in vitro and in vivo by genistein. Nutr Cancer 20, 1-12.

213. Patel RP, Boersma BJ, Crawford JH, Hogg N, Kirk M, Kalyanaraman B, Parks DA, Barnes S \& Darley-Usmar V (2001) Antioxidant mechanisms of isoflavones in lipid systems: paradoxical effects of peroxyl radical scavenging. Free Radic Biol Med 31, 1570-1581.

214. Raschke M, Rowland IR, Magee PJ \& Pool-Zobel BL (2006) Genistein protects prostate cells against hydrogen peroxideinduced DNA damage and induces expression of genes involved in the defence against oxidative stress. Carcinogenesis 27, 2322-2330.

215. DiSilvestro RA, Goodman J, Dy E \& Lavalle G (2005) Soy isoflavone supplementation elevates erythrocyte superoxide dismutase, but not plasma ceruloplasmin in postmenopausal breast cancer survivors. Breast Cancer Res Treat 89, 251-255.

216. Rowlands JC, He L, Hakkak R, Ronis MJ \& Badger TM (2001) Soy and whey proteins downregulate DMBA-induced liver and mammary gland CYP1 expression in female rats. J Nutr 131, 3281-3287.

217. Chan HY \& Leung LK (2003) A potential protective mechanism of soya isoflavones against 7,12-dimethylbenz[ $a$ ]anthracene tumour initiation. Br J Nutr 90, 457-465.

218. Peng WX, Li HD \& Zhou HH (2003) Effect of daidzein on CYP1A2 activity and pharmacokinetics of theophylline in healthy volunteers. Eur J Clin Pharmacol 59, 237-241.

219. Steiner C, Peters WH, Gallagher EP, Magee P, Rowland I \& Pool-Zobel BL (2007) Genistein protects human mammary epithelial cells from benzo(a)pyrene-7,8-dihydrodiol-9,10epoxide and 4-hydroxy-2-nonenal genotoxicity by modulating the glutathione/glutathione $S$-transferase system. Carcinogenesis 28, 738-748.

220. Bianco NR, Chaplin LJ \& Montano MM (2005) Differential induction of quinone reductase by phytoestrogens and protection against oestrogen-induced DNA damage. Biochem $J$ 385, 279-287.

221. Farhan H, Wahala K \& Cross HS (2003) Genistein inhibits vitamin D hydroxylases CYP24 and CYP27B1 expression in prostate cells. J Steroid Biochem Mol Biol 84, 423-429.

222. Cross HS, Kallay E, Lechner D, Gerdenitsch W, Adlercreutz H \& Armbrecht HJ (2004) Phytoestrogens and vitamin D metabolism: a new concept for the prevention and therapy of colorectal, prostate, and mammary carcinomas. J Nutr 134, $1207 \mathrm{~S}-1212 \mathrm{~S}$.

223. Markovits J, Linassier C, Fosse P, Couprie J, Pierre J, Jacquemin-Sablon A, Saucier JM, Le Pecq JB \& Larsen AK (1989) Inhibitory effects of the tyrosine kinase inhibitor genistein on mammalian DNA topoisomerase II. Cancer Res 49, 5111-5117.

224. Chinni SR, Alhasan SA, Multani AS, Pathak S \& Sarkar FH (2003) Pleotropic effects of genistein on MCF-7 breast cancer cells. Int J Mol Med 12, 29-34.

225. Lila MA \& Raskin I (2005) Health-related interactions of phytochemicals. J Food Sci 70, R20-R27.

226. Lee AV, Cui XJ \& Oesterreich S (2001) Cross-talk among estrogen receptor, epidermal growth factor, and insulin-like growth factor signaling in breast cancer. Clin Cancer Res 7, 4429S-4435S.

227. Ueda T, Mawji NR, Bruchovsky N \& Sadar MD (2002) Ligand-independent activation of the androgen receptor by interleukin-6 and the role of steroid receptor coactivator-1 in prostate cancer cells. J Biol Chem 277, 38087-38094.

228. Kato S, Masuhiro Y, Watanabe M, Kobayashi Y, Takeyama K, Endoh H \& Yanagisawa J (2000) Molecular mechanism of a cross-talk between oestrogen and growth factor signalling pathways. Genes Cells 5, 593-601.

229. McCarty MF (2004) Targeting Multiple signaling pathways as a strategy for managing prostate cancer: multifocal signal modulation therapy. Integr Cancer Ther 3, 349-380.

230. Hamelers IHL \& Steenbergh PH (2003) Interactions between insulin-like growth factor estrogen and signaling pathways in human breast tumor cells. Endocr Relat Cancer 10, 331-345.

231. Wang X \& Kilgore MW (2002) Signal cross-talk between estrogen receptor alpha and beta and the peroxisome proliferator-activated receptor gamina1 in MDA-MB-231 and MCF-7 breast cancer cells. Mol Cell Endocrinol 194, 123-133.

232. Bonofiglio D, Gabriele S, Aquila S, Catalano S, Gentile M, Middea E, Giordano F \& Ando S (2005) Estrogen receptor alpha binds to peroxisome proliferator-activated receptor response element and negatively interferes with peroxisome proliferator-activated receptor gamma signaling in breast cancer cells. Clin Cancer Res 11, 6139-6147.

233. De Bosscher K, Vanden Berghe W \& Haegeman G (2006) Cross-talk between nuclear receptors and nuclear factor kappa B. Oncogene 25, 6868-6886.

234. Vasudevan KM, Gurumurthy S \& Rangnekar VM (2004) Suppression of PTEN expression by NF-kappa B prevents apoptosis. Mol Cell Biol 24, 1007-1021.

235. Terasaka S, Aita Y, Inoue A, Hayashi S, Nishigaki M, Aoyagi K, Sasaki H, Wada-Kiyama Y, Sakuma Y, Akaba S, Tanaka J, Sone H, Yonemoto J, Tanji M \& Kiyama R (2004) Using a customized DNA microarray for expression profiling of the estrogen-responsive genes to evaluate estrogen activity among natural estrogens and industrial chemicals. Environ Health Perspect 112, 773-781.

236. Ise R, Han D, Takahashi Y, Terasaka S, Inoue A, Tanji M \& Kiyama R (2005) Expression profiling of the estrogen responsive genes in response to phytoestrogens using a customized DNA microarray. FEBS Lett 579, 1732-1740.

237. Moggs JG, Ashby J, Tinwell H, Lim FL, Moore DJ, Kimber I \& Orphanides G (2004) The need to decide if all estrogens are intrinsically similar. Environ Health Perspect 112, $1137-1142$.

238. Naciff JM, Jump ML, Torontali SM, Carr GJ, Tiesman JP, Overmann GJ \& Daston GP (2002) Gene expression profile induced by 17alpha-ethynyl estradiol, bisphenol A, and genistein in the developing female reproductive system of the rat. Toxicol Sci 68, 184-199. 
239. Konstantakopoulos N, Montgomery KG, Chamberlain N, Quinn MA, Baker MS, Rice GE, Georgiou HM \& Campbell IG (2006) Changes in gene expressions elicited by physiological concentrations of genistein on human endometrial cancer cells. Mol Carcinog 45, 752-763.

240. Naciff JM \& Daston GP (2004) Toxicogenomic approach to endocrine disrupters: identification of a transcript profile characteristic of chemicals with estrogenic activity. Toxicol Pathol 32, 59-70.

241. Shioda T, Chesnes J, Coser KR, Zou LH, Hur J, Dean KL, Sonnenschein C, Soto AM \& Isselbacher KJ (2006) Importance of dosage standardization for interpreting transcriptomal signature profiles: evidence from studies of xenoestrogens. Proc Natl Acad Sci U S A 103, 12033-12038.

242. Buterin T, Koch C \& Naegeli H (2006) Convergent transcriptional profiles induced by endogenous estrogen and distinct xenoestrogens in breast cancer cells. Carcinogenesis 27, 1567-1578.

243. Thomsen AR, Almstrup K, Nielsen JE, Sorensen IK, Petersen OW, Leffers H \& Breinholt VM (2006) Estrogenic effect of soy isoflavones on mammary gland morphogenesis and gene expression profile. Toxicol Sci 93, 357-368.

244. York TP, Plymate SR, Nelson PS, Eaves LJ, Webb HD \& Ware JL (2005) cDNA microarray analysis identifies genes induced in common by peptide growth factors and androgen in human prostate epithelial cells. Mol Carcinog 44, 242-251.

245. You L \& Bartolucci EJ (2004) Gene expression profiles in mammary gland of male rats treated with genistein and methoxychlor. Environ Toxicol Pharmacol 18, 161-172.

246. Takahashi Y, Lavigne JA, Hursting SD, Chandramouli GVR, Perkins SN, Barrett JC \& Wang TTY (2004) Using DNA microarray analyses to elucidate the effects of genistein in androgen-responsive prostate cancer cells: identification of novel targets. Mol Carcinog 41, 108-119.

247. Takahashi Y, Lavigne JA, Hursting SD, Chandramouli GVR, Perkins SN, Kim YS \& Wang TTY (2006) Molecular signatures of soy-derived phytochemicals in androgen-responsive prostate cancer cells: a comparison study using DNA microarray. Mol Carcinog 45, 943-956.

248. Takahashi Y, Hursting SD, Perkins SN, Wang TC \& Wang TTY (2006) Genistein affects androgen-responsive genes through both androgen- and estrogen-induced signaling pathways. Mol Carcinog 45, 18-25.

249. Li YW, Che MX, Bhagat S, Ellis KL, Kucuk O, Doerge DR, Abrams J, Cher ML \& Sarkar FH (2004) Regulation of gene expression and inhibition of experimental prostate cancer bone metastasis by dietary genistein. Neoplasia 6, 354-363.

250. Suzuki K, Koike H, Matsui H, Ono Y, Hasumi M, Nakazato H, Okugi H, Sekine Y, Oki K, Ito K, Yamamoto T, Fukabori Y, Kurokawa K \& Yamanaka H (2002) Genistein, a soy isoflavone, induces glutathione peroxidase in the human prostate cancer cell lines LNCaP and PC-3. Int J Cancer 99, 846-852.

251. Chen WF, Huang MH, Tzang $\mathrm{CH}$, Yang $\mathrm{M} \&$ Wong MS (2003) Inhibitory actions of genistein in human breast cancer (MCF-7) cells. Biochim Biophys Acta 1638, 187-196.

252. Handayani R, Rice L, Cui Y, Medrano TA, Samedi VG, Baker HV, Szabo NJ \& Shiverick KT (2006) Soy isoflavones alter expression of genes associated with cancer progression, including interleukin- 8 , in androgen-independent PC-3 human prostate cancer cells. $J$ Nutr 136, 75-82.

253. Rowell C, Carpenter DM \& Lamartiniere CA (2005) Chemoprevention of breast cancer, proteomic discovery of genistein action in the rat mammary gland. J Nutr 135, 2953S-2959S.

254. Solanky KS, Bailey NJ, Beckwith-Hall BM, Bingham S, Davis A, Holmes E, Nicholson JK \& Cassidy A (2005) Biofluid H-1 NMR-based metabonomic techniques in nutrition research metabolic effects of dietary isoflavones in humans. $J$ Nutr Biochem 16, 236-244.
255. Solanky KS, Bailey NJC, Beckwith-Hall BM, Davis A, Bingham S, Holmes E, Nicholson JK \& Cassidy A (2003) Application of biofluid $\mathrm{H}-1$ nuclear magnetic resonance-based metabonomic techniques for the analysis of the biochemical effects of dietary isoflavones on human plasma profile. Anal Biochem 323, 197-204.

256. Gibney MJ, Walsh M, Brennan L, Roche HM, German B \& van Ommen B (2005) Metabolomics in human nutrition: opportunities and challenges. Am J Clin Nutr 82, 497-503.

257. Fay JR, Crowell JA \& Kopelovich L (2005) Targeting epigenetic regulatory mechanisms in cancer chemoprevention. Expert Opin Ther Targets 9, 315-328.

258. Leader JE, Wang C, Fu M \& Pestell RG (2006) Epigenetic regulation of nuclear steroid receptors. Biochem Pharmacol 72, 1589-1596

259. Yu YP, Paranjpe S, Nelson J, Finkelstein S, Ren B, Kokkinakis D, Michalopoulos G \& Luo JH (2005) High throughput screening of methylation status of genes in prostate cancer using an oligonucleotide methylation array. Carcinogenesis 26, 471-479.

260. Day JK, Bauer AM, DesBordes C, Zhuang Y, Kim BE, Newton LG, Nehra V, Forsee KM, MacDonald RS, BeschWilliford C, Huang TH \& Lubahn DB (2002) Genistein alters methylation patterns in mice. J Nutr 132, 2419S-2423S.

261. Fang MZ, Chen D, Sun Y, Jin Z, Christman JK \& Yang CS (2005) Reversal of hypermethylation and reactivation of p16INK4a, RARbeta, and MGMT genes by genistein and other isoflavones from soy. Clin Cancer Res 11, 7033-7041.

262. Hong T, Nakagawa T, Pan WJ, Kim MY, Kraus WL, Ikehara T, Yasui K, Aihara H, Takebe M, Muramatsu M \& Ito T (2004) Isoflavones stimulate estrogen receptor-mediated core histone acetylation. Biochem Biophys Res Commun 317, 259-264.

263. Lund TD, Munson DJ, Adlercreutz H, Handa RJ \& Lephart ED (2004) Androgen receptor expression in the rat prostate is down-regulated by dietary phytoestrogens. Reprod Biol Endocrinol 2, 5-10.

264. Wong CK \& Keung WM (1999) Bovine adrenal 3betahydroxysteroid dehydrogenase (E.C. 1.1.1. 145)/5-ene-4-ene isomerase (E.C. 5.3.3.1): characterization and its inhibition by isoflavones. J Steroid Biochem Mol Biol 71, 191-202.

265. Hiipakka RA, Zhang HZ, Dai W, Dai Q \& Liao ST (2002) Structure-activity relationships for inhibition of human 5 alphareductases by polyphenols. Biochem Pharmacol 63,1165-1176.

266. Adlercreutz H, Hockerstedt K, Bannwart C, Bloigu S, Hamalainen E, Fotsis T \& Ollus A (1987) Effect of dietary components, including lignans and phytoestrogens, on enterohepatic circulation and liver metabolism of estrogens and on sex hormone binding globulin (SHBG). J Steroid Biochem 27, 1135-1144.

267. Pino AM, Valladares LE, Palma MA, Mancilla AM, Yanez M \& Albala C (2000) Dietary isoflavones affect sex hormonebinding globulin levels in postmenopausal women. $J$ Clin Endocrinol Metab 85, 2797-2800.

268. Brzezinski A, Adlercreutz H, Shaoul R, Rosler A, Shmueli A, Tanos V \& Schenker JG (1997) Short-term effects of phytoestrogen-rich diet on postmenopausal women. Menopause 4 $89-94$.

269. Goodin S, Shen F, Shih WJ, Dave N, Kane MP, Medina P, Lambert GH, Aisner J, Gallo M \& DiPaola RS (2007) Clinical and biological activity of soy protein powder supplementation in healthy male volunteers. Cancer Epidemiol Biomarkers Prev 16, 829-833.

270. Rannikko A, Petas A, Raivio T, Janne OA, Rannikko S \& Adlercreutz H (2006) The effects of short-term oral phytoestrogen supplementation on the hypothalamic-pituitary-testicular axis in prostate cancer patients. Prostate 66, 1086-1091.

271. Shao ZM, Alpaugh ML, Fontana JA \& Barsky SH (1998) Genistein inhibits proliferation similarly in estrogen receptor-positive 
and negative human breast carcinoma cell lines characterized by P21(WAF1/CIP1) induction, G(2)/M arrest, and apoptosis. J Cell Biochem 69, 44-54.

272. Katdare M, Osborne M \& Telang NT (2002) Soy isoflavone genistein modulates cell cycle progression and induces apoptosis in HER-2/neu oncogene expressing human breast epithelial cells. Int J Oncol 21, 809-815.

273. Li Y \& Sarkar FH (2002) Inhibition of nuclear factor kappaB activation in PC 3 cells by genistein is mediated via Akt signaling pathway. Clin Cancer Res 8, 2369-2377.

274. Berghe WV, Dijsselbloem N, Vermeulen L, Ndlovu MN, Boone E \& Haegeman G (2006) Attenuation of mitogenand stress-activated protein kinase-1-driven nuclear factorkappa B gene expression by soy isoflavones does not require estrogenic activity. Cancer Res 66, 4852-4862.

275. Laurenzana EM, Weis CC, Bryant CW, Newbold R \& Delclos KB (2002) Effect of dietary administration of genistein, nonylphenol or ethinyl estradiol on hepatic testosterone metabolism, cytochrome P-450 enzymes, and estrogen receptor alpha expression. Food Chem Toxicol 40, 53-63.

276. van Duursen MB, Sanderson JT, de Jong PC, Kraaij M \& van den Berg M (2004) Phytochemicals inhibit catechol-O-methyltransferase activity in cytosolic fractions from healthy human mammary tissues: implications for catechol estrogen-induced DNA damage. Toxicol Sci 81, 316-324.

277. Appelt LC \& Reicks MM (1999) Soy induces phase II enzymes but does not inhibit dimethylbenz $[a]$ anthraceneinduced carcinogenesis in female rats. $J$ Nutr 129, $1820-1826$.

278. Eaton EA, Walle UK, Lewis AJ, Hudson T, Wilson AA \& Walle $\mathrm{T}$ (1996) Flavonoids, potent inhibitors of the human P-form phenolsulfotransferase. Potential role in drug metabolism and chemoprevention. Drug Metab Dispos 24, 232-237. 